\title{
Activation of Ilmenite as an Oxygen Carrier for Solid-fueled Chemical Looping Combustion
}

\author{
Liangyong Chen ${ }^{\mathrm{a}}$, Jinhua Bao ${ }^{\mathrm{a}}$, Liang Kong ${ }^{\mathrm{a}}$, Megan Combs ${ }^{\mathrm{a}}$, Heather S Nikolic ${ }^{\mathrm{a}}$, Zhen Fan ${ }^{\mathrm{a}}$, and Kunlei Liu ${ }^{\mathrm{a}, \mathrm{b} *}$ \\ a. Center for Applied Energy Research, University of Kentucky, 2540 Research Park Drive, Lexington, KY 40511- \\ 8410, United States \\ b. Department of Mechanical Engineering, University of Kentucky, Lexington, KY 40506, United States \\ *Corresponding author: (+1) 859257 0293; E-mail address: kunlei.liu@uky.edu
}

\begin{abstract}
Ilmenite ore is one of the promising oxygen carriers (OCs) used for coal-fueled ChemicalLooping Combustion (CLC) for electricity generation and $\mathrm{CO}_{2}$ capture. However, the low reactivity and natural activation of ilmenite $\mathrm{OC}$ are two major constrains impeding its application. This effort is to improve ilmenite OC's performance by introducing a small amount of foreign elements, including alkali or alkaline earth metals ( $\mathrm{K}$ and $\mathrm{Ca})$ and transition metals $(\mathrm{Cu}, \mathrm{Mn}$, and $\mathrm{Ni})$. Coating and re-granulation methods were used to prepare OCs where ilmenite ore was the primary constituent. The reactivity, transport capacity, and selectivity of these ilmenite-based OCs with wet syngas, as well as their performances in coal char-fueled CLC were investigated using a TGA, fixed- and fluidized-bed reactors. The addition of K-element significantly improved the OC's reactivity with wet syngas and coal char. The strong catalytic function for WGSR from $\mathrm{K}$-added OCs was found to play a vital role. Cu-coating hindered effectively Fe-element segregation on the surface of ilmenite OC during cyclic reaction, and the OC structural integrity was well maintained. $\mathrm{Ca}-$, Ni- and Mn-added ilmenite OCs did not show promising prospects. The gasification rate and combustion efficiency could be respectively correlated to the reactivity and selectivity of different OCs except for the K-added samples.
\end{abstract}

Key words: Chemical looping combustion; Iron-based oxygen carrier; Ilmenite; Solid fuel

\section{Introduction}

Due to the impact of $\mathrm{CO}_{2}$ emissions on climate change, reducing $\mathrm{CO}_{2}$ production from fossil fuel combustion, including coal combustion is an agent need. The novel process of coal-fueled CLC with ironbased OCs has been extensively studied for simultaneous electricity generation and $\mathrm{CO}_{2}$ capture [1, 2]. Compared to post-combustion technologies, the coal-fueled CLC technology possesses much lower energy penalties for $\mathrm{CO}_{2}$ capture by avoiding costly gas separation processes. The plant efficiency of the coal-fueled CLC is approximately $36 \%$ with ambient pressure [3] and as high as $42-43 \%$ with the pressurized combined cycle [4]. The key to successful CLC process is to develop an optimal OC material. The following OC criteria are needed $[1,5]$

- High reactivity with fuel and oxygen

- High fuel conversion to $\mathrm{CO}_{2}$ and $\mathrm{H}_{2} \mathrm{O}$, or high selectivity for high purity $\mathrm{CO}_{2}$ stream

- High oxygen transport capacity to minimize solid circulation

- Chemical and mechanical stability during successive redox cycles

- High resistance to attrition if a fluidized bed reactor is used

- No carbon deposition to avoid release carbon as $\mathrm{CO}_{2}$ in the air reactor (AR)

- Environmentally safe and non-hazardous 
These properties above should remain in long term operation. For the solid-fueled CLC, OCs should also be highly ash-resistant because they are directly mixed with coal ash in the fuel reactor (FR). Otherwise, agglomeration and reactivity decay are unavoidable. In order to avoid coal ash accumulation in the system, separating coal ash from the bio-mixtures is needed, but this will lead to appreciable loss of OCs with coal ash stream. Thus, low-cost iron-based OC materials, especially solid waste and natural materials are more favorable for the combustion of solid fuel [6]. A significant improvement in gasification rate in the FR can be realized by using proper OCs [7]. The presence of OC rapidly lowers the fraction of intermediate syngas, $\mathrm{CO}$ and $\mathrm{H}_{2}$, both of which are gasification inhibitors [8]. High reactive with syngas components is one of the most important properties of an OC desired for the solid-fueled CLC.

\begin{tabular}{|c|c|c|c|}
\hline $\begin{array}{l}\text { Nom } \\
d_{50}\end{array}$ & $\begin{array}{l}\text { clature } \\
\text { median diameter }(\mu \mathrm{m})\end{array}$ & $\begin{array}{l}\text { Greek } \\
\text { Letters }\end{array}$ & \\
\hline$f_{\mathrm{i}}$ & volumetric fraction of $i$ gas component & $\eta_{\mathrm{syn}}$ & $\begin{array}{l}\text { combustion efficiency of } \\
\text { intermediate syngas in the solid- } \\
\text { fueled CLC }\end{array}$ \\
\hline$J$ & quotient of WGSR reaction & $\eta_{\mathrm{syn}}$ & average combustion efficiency \\
\hline$K_{\text {eq }}$ & equilibrium constant of $W G S R$ & $\Delta X_{\mathrm{OC}}^{\prime}$ & $\begin{array}{l}\text { the amount of oxygen transferred to } \\
\text { fuels/total mass of OC }\end{array}$ \\
\hline$m$ & mass of OC during reduction $(\mathrm{g})$ & & \\
\hline$m_{\mathrm{C}}(t)$ & $\begin{array}{l}\text { total mass of carbon in fuel char converted to gas } \\
\text { at time of } t(\mathrm{~g})\end{array}$ & Acronyms & \\
\hline$m_{\mathrm{ox}}$ & mass of $\mathrm{OC}$ in the full oxidized form $(\mathrm{g})$ & AR & Air Reactor \\
\hline$m_{\text {total }}$ & total mass of carbon introduced to the reactor $(\mathrm{g})$ & CFB & Circulating Fluidized Bed \\
\hline$m_{\text {red }}$ & $\begin{array}{l}\text { mass of } \mathrm{OC} \text { in the reduced form obtained under } \\
\text { experimental condition }(\mathrm{g})\end{array}$ & CLC & Chemical Looping Combustion \\
\hline$P_{\mathrm{i}}$ & integral partial pressure of syngas component $i$ & FR & Fuel Reactor \\
\hline$r_{\mathrm{OC}}$ & mass-based conversion of OC per unit time & FG & Freeze Granulation \\
\hline$\overline{r_{\mathrm{C}}}$ & average carbon conversion rate & $\mathrm{OC}$ & Oxygen Carrier \\
\hline$S_{\text {syn }}$ & instantaneous selectivity during $\mathrm{OC}$ reduction & TGA & Thermogravimetric Analyzer \\
\hline$S_{\mathrm{syn}}^{--}$ & average of OC's instantaneous selectivity & $W G S R$ & Water-Gas-Shift Reaction \\
\hline$t$ & time $(\min )$ & XRD & X-ray Diffraction \\
\hline$T$ & temperature $(\mathrm{K})$ & XRF & $\mathrm{X}$-ray fluorescence \\
\hline$X_{\mathrm{OC}}$ & Mass-based conversion of oxygen carriers & & \\
\hline
\end{tabular}

Among iron-based OCs, ilmenite ore is a suitable material for coal-fueled CLC [9]. Ilmenite ore, naturally in a reduced form, is primarily composed of $\mathrm{FeTiO}_{3}$. Its full oxidized form contains $\mathrm{Fe}_{2} \mathrm{TiO}_{5}, \mathrm{TiO}_{2}$ and a small amount of $\mathrm{Fe}_{2} \mathrm{O}_{3}$. When it is used as $\mathrm{OCs}, \mathrm{Fe}_{2} \mathrm{TiO}_{5}$ and $\mathrm{Fe}_{2} \mathrm{O}_{3}$ are the active phases. Ilmenite has been investigated as one of the most promising OC material for the future commercial application [9-12]. Compared to other iron-based OCs, ilmenite possesses high oxygen transport capacity. The major component of ilmenite, $\mathrm{Fe}_{2} \mathrm{TiO}_{5}$, is reduced to $\mathrm{FeTiO}_{3}$ in CLC process [9], resulting in a lattice oxygen transport capacity of $5.0 \mathrm{wt}$.\%. Both $\mathrm{Fe}_{2} \mathrm{TiO}_{5}$ and $\mathrm{Fe}_{2} \mathrm{O}_{3}$ in ilmenite $\mathrm{OC}$ have favorable thermodynamics to convert syngas to $\mathrm{CO}$ and $\mathrm{H}_{2} \mathrm{O}$. The equilibrium constants of the two redox systems $\left(\mathrm{Fe}_{2} \mathrm{TiO}_{5} / \mathrm{FeTiO}_{3}\right.$ and $\mathrm{Fe}_{2} \mathrm{O}_{3} / \mathrm{Fe}_{3} \mathrm{O}_{4}$ ) are higher than $10^{3}$, suggesting almost complete fuel conversion [1]. High conversion and reactivity of ilmenite ore OCs with syngas were also confirmed experimentally [13]. The oxidation of the reduced ilmenite is a fast reaction, and during multi-redox cycle, complete re-oxidation of each cycle could be reached [9]. The performance of ilmenite OCs used for coal-fueled CLC had been tested in a batch fluidized bed reactor and the influences of gasification agent and temperature were investigated [14]. An ilmenite OC was first tested in continuous mode in a $10 \mathrm{KW}_{\text {th }}$ CLC unit using coal and petro-coke as 
fuel at Chalmers University of Technology [15-16]. The results from these studies showed favorable OC fluidization properties and high agglomeration resistance. Technische University Darmstadt (Germany) successfully demonstrated an auto-thermal operation of a $1 \mathrm{MW}_{\text {th }}$ CLC unit using ilmenite OC and hard coal [17] despite the low conversion of intermediate syngas and solid char in the FR. A detailed engineering design of coal-fueled CLC boiler was performed at a commercial scale $\left(1,000 \mathrm{MW}_{\text {th }}\right)$, where ilmenite ore was selected as the OCs to investigate the mass and heat balance, gas-solid flow, solid inventory, combustor configuration, and the cost of boiler [18].

The reaction rate of ilmenite $\mathrm{OC}$ with either $\mathrm{CO}$ or $\mathrm{H}_{2}$ is high, but ilmenite's ability to enhance gasification in CLC has been reported as lower relative to other active OCs, such as iron- and manganeseores $[19,7]$. The in-situ gasification rate of CLC with ilmenite OCs is about $30 \%$ higher than the external gasification [14]. Because relatively low temperature is adopted in CLC process where the gasification reaction is chemically controlled, the improved gasification due to the use of ilmenite OC would not likely lead to a significant difference. With slow gasification, a certain amount of unconverted coal char would slip into the AR with the OC stream, significantly lowering the carbon capture efficiency. Therefore, improving the reactivity of ilmenite with solid fuel is necessary. The natural activation of ilmenite in successive redox cycles, as it can be found when using both gaseous and solid fuels [20, 12], may cause negative impact. Natural-activation slightly increases OC reactivity but decreases the oxygen transport capacity because more $\mathrm{Fe}_{2} \mathrm{O}_{3}$ phase is created from the decomposition of $\mathrm{Fe}_{2} \mathrm{TiO}_{5}$. The natural activation process is accompanied by the gradual formation of an external $\mathrm{Fe}_{2} \mathrm{O}_{3}$-rich layer, which leads to easier particle rounding and detachment of the external layer. Because of these disadvantages, the lifetime of ilmenite OC is estimated at 1,700 hours for the operation of CFB reactor [21].

Not much research has focus on improving the performance of ilmenite OCs for the gas-fueled CLC process. A physical mixed oxide of ilmenite and $\mathrm{NiO}_{2}$-based $\mathrm{OC}$ was reported to outperform ilmenite for $\mathrm{CH}_{4}$ combustion [5]. Metallic $\mathrm{Ni}$ is believed to catalyze the decomposition of $\mathrm{CH}_{4}$ into reactive intermediates, $\mathrm{CO}$ and $\mathrm{H}_{2}$. Bao et al. found that the reduction reactivity of ilmenite OC impregnated with $15 \mathrm{wt} \% \mathrm{~K}^{+}$was 8 times faster than that of the raw ilmenite when $\mathrm{CO}$ was used as fuel [22].

The focus of this study is to improve the performance of ilmenite OCs for the solid-fueled CLC by introducing a small amount of foreign elements to OC particles. Re-granulation and coating methods were used to prepare the ilmenite-based OCs. The elements used are categorized into two groups: 1.) Alkali or alkaline earth metals ( $\mathrm{K}$ and $\mathrm{Ca}$ ) and 2.) Transition metals ( $\mathrm{Cu}, \mathrm{Mn}$ and $\mathrm{Ni}$ ). It is believed that the addition of alien elements may alter the OC's performance by changing the pathway of OC reduction, altering the lattice oxygen transfer, or by forming a new crystalline phase that is more reducible. The experiments performed focusing on reactivity, oxygen transport capacity, and selectivity of converting wet syngas, and the OCs' performances in coal char-fueled CLC. This work also tentatively reveals the mechanism for the improved OC performance.

\section{Experimental}

\subsection{Materials}

Before the preparation of various ilmenite-based OCs, raw ilmenite ore (125-355 $\mu \mathrm{m})$ was stabilized in air at $950{ }^{\circ} \mathrm{C}$ for 24 hours. The ilmenite $(200.0 \mathrm{~g}$ for each batch) was then activated by 5 redox cycles in a fixed reactor. A gas stream containing $2.0 \mathrm{NL} / \mathrm{min} \mathrm{CO}, 1.5 \mathrm{~g} / \mathrm{min}$ steam, and $2.0 \mathrm{NL} / \mathrm{min}_{2}$ was used in 10 -minute reduction at $950{ }^{\circ} \mathrm{C}$, while 10 vol. $\% \mathrm{O}_{2}$ was introduced during regeneration. The chemical 
composition of the activated ilmenite in its fully oxidized form is $52.87 \% \mathrm{Fe}_{2} \mathrm{O}_{3}, 33.8 \% \mathrm{TiO}_{2}, 5.7 \% \mathrm{SiO}_{2}$, $3.6 \% \mathrm{Al}_{2} \mathrm{O}_{3}, 2.8 \% \mathrm{MgO}$ and $0.9 \% \mathrm{CaO}$.

The activated ilmenite $(125-355 \mu \mathrm{m})$ and its crushed powder $\left(d_{50}=19.5 \mu \mathrm{m}\right)$ were the main components used to prepare the OCs by coating and freeze granulation (FG) methods, respectively. The foreign elements, including $\mathrm{K}, \mathrm{Ca}, \mathrm{Cu}, \mathrm{Mn}$ and $\mathrm{Ni}$, were added to ilmenite in their nitrates, which were converted to oxidates during calcination. In the FG method, $200.0 \mathrm{~g}$ of fine powder, the desired amount of nitrates, $330.0 \mathrm{~g}$ deionized water, and $50.0 \mathrm{~g}$ polyvinyl alcohol (Sigma-Aldrich, St. Louis, MO) was mixed to make into homogenous slurry. The slurry was then sprayed into liquid nitrogen to form frozen spherical particles, which were subsequently dried in a vacuum freeze dryer. Finally, calcination was performed at high temperature to stabilize the foreign elements and to provide sufficient mechanical strength. In the coating method, $200.0 \mathrm{~g}$ of activated ilmenite was poured into the prepared solutions $(100.0 \mathrm{~g}$ deionized water and the desired amount of nitrates), stirred for 24 hours, and dried at $95{ }^{\circ} \mathrm{C}$. The dry samples were then calcinated at $950{ }^{\circ} \mathrm{C}$ for 6 hours. The activated ilmenite and FG samples without the addition of foreign element were used as references. The particle size of the OCs used for experimentation was 125 to $355 \mu \mathrm{m}$. Their designations and properties are listed in Table $\mathbf{1}$.

Coal char $(d=180-355 \mu \mathrm{m})$, prepared from Power River Basin coal, was used as fuel. During preparation, the parent coal was heated in a fixed bed reactor at $800{ }^{\circ} \mathrm{C}$ for $20 \mathrm{~min} .3 .0 \mathrm{NL} / \mathrm{min}$ of $\mathrm{N}_{2}$ flow was used to carry the gas products out of the reactor during pyrolysis. The proximate and ultimate analyses and ash analysis of PRB coal char are presented in Table 2 and Table 3. Here the ash sample was obtained from steam-char gasification at $950{ }^{\circ} \mathrm{C}$, and its composition was determined with XRF analysis.

Table 1 Ilmenite-based oxygen carriers

\begin{tabular}{|c|c|c|c|c|c|}
\hline Sample & $\begin{array}{l}\text { Fraction of } \\
\text { alien } \\
\text { elements* }\end{array}$ & $\begin{array}{l}\text { Calcination } \\
\text { Temperature }\end{array}$ & $\begin{array}{c}\text { BET } \\
\text { Surface } \\
\text { Area }\end{array}$ & $\begin{array}{l}\text { Crushing } \\
\text { Strength }\end{array}$ & XRD Analysis (oxidized form) \\
\hline \multirow[b]{2}{*}{ Activated-I } & Wt.\% & ${ }^{\circ} \mathrm{C}$ & $\mathrm{m}^{2} / \mathrm{g}$ & $\mathrm{N}$ & \\
\hline & - & 950 & 0.28 & 4.5 & $\mathrm{Fe}_{2} \mathrm{TiO}_{5}, \mathrm{TiO}_{2}$ \\
\hline - Used & & & 0.40 & 3.7 & $\mathrm{Fe}_{2} \mathrm{TiO}_{5}, \mathrm{Fe}_{2} \mathrm{O}_{3}, \mathrm{SiO}_{2}$ \\
\hline FG-I & - & 1100 & 0.46 & 2.5 & $\mathrm{Fe}_{2} \mathrm{TiO}_{5}$ \\
\hline $\mathrm{SK}_{2} \mathrm{O}(5)-\mathrm{I}$ & 5.0 & 950 & 0.24 & 4.7 & $\begin{array}{l}\mathrm{Fe}_{2} \mathrm{TiO}_{5}, \mathrm{Fe}_{2} \mathrm{O}_{3}, \mathrm{~K}_{2}\left(\mathrm{Ti}_{8} \mathrm{O}_{17}\right), \\
\mathrm{K}_{1.46} \mathrm{Ti}_{7.2} \mathrm{Fe}_{0.8} \mathrm{O}_{16}\end{array}$ \\
\hline - Used & & & 0.26 & 3.2 & $\mathrm{Fe}_{2} \mathrm{TiO}_{5}, \mathrm{Fe}_{2} \mathrm{O}_{3}, \mathrm{~K}_{1.46} \mathrm{Ti}_{7.2} \mathrm{Fe}_{0.8} \mathrm{O}_{16}$ \\
\hline FG-I- $\mathrm{K}_{2} \mathrm{O}(5)$ & 5.0 & 1100 & 0.44 & 2.3 & $\mathrm{Fe}_{2} \mathrm{TiO}_{5}, \mathrm{Fe}_{2} \mathrm{O}_{3}, \mathrm{~K}_{1.46} \mathrm{Ti}_{7.2} \mathrm{Fe}_{0.8} \mathrm{O}_{16}$ \\
\hline - Used & & & 0.22 & 2.1 & $\mathrm{Fe}_{2} \mathrm{TiO}_{5}, \mathrm{Fe}_{2} \mathrm{O}_{3}, \mathrm{~K}_{1.46} \mathrm{Ti}_{7.2} \mathrm{Fe}_{0.8} \mathrm{O}_{16}$ \\
\hline FG-I-CaO(5) & 5.0 & 1200 & 0.25 & 2.6 & $\mathrm{Fe}_{2} \mathrm{TiO}_{5}, \mathrm{Fe}_{2} \mathrm{O}_{3}, \mathrm{CaO}, \mathrm{Ca}\left(\mathrm{Ti}_{0.8} \mathrm{Fe}_{0.2}\right) \mathrm{O}_{2.9}$ \\
\hline $\mathrm{SCuO}(5)-\mathrm{I}$ & 5.0 & 950 & 0.11 & 4.5 & $\mathrm{Fe}_{2} \mathrm{TiO}_{5}, \mathrm{Fe}_{2} \mathrm{O}_{3}, \mathrm{SiO}_{2}, \mathrm{Cu}_{3} \mathrm{TiO}_{4}$ \\
\hline - Used & & & 0.15 & 4.4 & $\mathrm{Fe}_{2} \mathrm{TiO}_{5}, \mathrm{Fe}_{2} \mathrm{O}_{3}, \mathrm{SiO}_{2}$ \\
\hline FG-I-CuO(5) & 5.0 & 1100 & 0.32 & 2.4 & $\mathrm{Fe}_{2} \mathrm{TiO}_{5}, \mathrm{Fe}_{2} \mathrm{O}_{3}, \mathrm{TiO}_{2}$ \\
\hline $\mathrm{SMn}_{3} \mathrm{O}_{4}(7.5)-\mathrm{I}$ & 7.5 & 950 & 0.14 & 4.3 & $\mathrm{Fe}_{3} \mathrm{Ti}_{3} \mathrm{O}_{10}, \mathrm{Fe}_{2} \mathrm{O}_{3}, \mathrm{MnO}_{2}, \mathrm{Mn}_{2} \mathrm{O}_{3}$ \\
\hline FG-I- $\mathrm{Mn}_{3} \mathrm{O}_{4}(7.5)$ & 7.5 & 1150 & 0.21 & 2.3 & $\mathrm{Fe}_{3} \mathrm{Ti}_{3} \mathrm{O}_{10}, \mathrm{Fe}_{2} \mathrm{O}_{3}, \mathrm{MnO}_{2}, \mathrm{Mn}_{2} \mathrm{O}_{3}$ \\
\hline $\mathrm{SNiO}_{2}(2.5)-\mathrm{I}$ & 2.5 & 950 & 0.22 & 4.4 & $\begin{array}{l}\mathrm{Fe}_{2} \mathrm{TiO}_{5}, \mathrm{Fe}_{2} \mathrm{O}_{3}, \mathrm{NiO}_{2}, \mathrm{Fe}_{3} \mathrm{Ti}_{3} \mathrm{O}_{10} \\
\mathrm{NiTiO}_{3}\end{array}$ \\
\hline FG-I-NiO $2(2.5)$ & 2.5 & 1150 & 0.39 & 2.2 & $\mathrm{Fe}_{2} \mathrm{TiO}_{5}, \mathrm{Fe}_{2} \mathrm{O}_{3}, \mathrm{NiO}_{2}, \mathrm{NiTiO}_{3}$ \\
\hline
\end{tabular}


Table 2 Proximate and ultimate analyses of PRB char

\begin{tabular}{|c|c|c|c|c|c|c|c|c|}
\hline \multirow{2}{*}{$\begin{array}{l}\text { Heating Value } \\
{[\mathrm{MJ} / \mathrm{kg}]}\end{array}$} & \multicolumn{3}{|c|}{ Proximate Analysis [wt.\%] } & \multicolumn{5}{|c|}{ Ultimate Analysis [wt. $\%$ ] } \\
\hline & Ash & Volatiles & Fixed carbon & $\mathrm{C}$ & $\mathrm{H}$ & $\mathrm{O}$ & $\mathrm{N}$ & $\mathrm{S}$ \\
\hline 27.6 & 16.28 & 3.13 & 80.59 & 77.4 & 1.38 & 1.52 & 1.72 & 1.70 \\
\hline
\end{tabular}

Table 3 Ash analysis of PRB char [wt.\%]

\begin{tabular}{cccccccccc}
\hline $\mathrm{SiO}_{2}$ & $\mathrm{Al}_{2} \mathrm{O}_{3}$ & $\mathrm{Fe}_{2} \mathrm{O}_{3}$ & $\mathrm{CaO}$ & $\mathrm{MgO}$ & $\mathrm{Na}_{2} \mathrm{O}$ & $\mathrm{K}_{2} \mathrm{O}$ & $\mathrm{P}_{2} \mathrm{O}_{5}$ & $\mathrm{TiO}_{2}$ & $\mathrm{SO}_{3}$ \\
\hline 47.31 & 17.57 & 6.1 & 15.28 & 4.16 & 1.0 & 0.85 & 1.39 & 0.96 & 6.15 \\
\hline
\end{tabular}

\subsection{Experiments and procedure}

A three-step strategy was implemented in this study. First, the reactivity and selectivity of ilmenite-based OCs were investigated with wet syngas (a mixture of CO and steam). Second, in-situ gasification and intermediate syngas conversion in the coal-char fueled CLC were evaluated in a fluidized bed reactor. Third, the stability and integrity of the best OCs were evaluated in cyclic CLC experiments, which demonstrate the materials' overall performance in the presence of fluidization flow, chemical reaction, and coal ash during long term operation. All experiments were performed at $950{ }^{\circ} \mathrm{C}$.

The reactivity of OCs in wet syngas was investigated in a TGA apparatus equipped with a steam generator (TGA, Netzsch STA 449 F3 Jupiter). 50-60 mg of fully oxidized sample was placed in the crucible and heated to the desired temperature in Ar. Then reduction was performed with a feed stream of $20 \mathrm{ml} / \mathrm{min} \mathrm{CO}, 0.03 \mathrm{~g} / \mathrm{min}$ steam, and $140 \mathrm{ml} / \mathrm{min} \mathrm{Ar}$ (corresponding to $10 \% \mathrm{CO}$ and $20 \%$ steam before the furnace). The flow rate of wet syngas was examined at which the external mass transfer limited reaction was avoided.

The OC selectivity was determined using a fixed-bed reactor with wet syngas at conditions of an ideal gas-solid contact. So the results revealed to what extent the wet syngas can be oxidized at different OC conversion. The schematic diagram and description of the fixed-bed facility can be found elsewhere [24]. This facility was also used in fluidized-bed mode for the coal char-fueled CLC experiments. During the fixed-bed experiments, the reducing gas was introduced at the top of reactor, while the resulting gas exited the bottom. The exit gas of the reactor was forced to pass through a cyclone, high temperature filter, cooler, and moisture trap in sequence to remove fine particles and condensate. The gas concentration profiles of $\mathrm{O}_{2}, \mathrm{CH}_{4}, \mathrm{CO}, \mathrm{CO}_{2}$, and $\mathrm{H}_{2}$ were analyzed by a multi-gas analyzer (Rosemount, $\mathrm{X}$-stream). The reducing gas flow, containing $1.5 \mathrm{NL} / \mathrm{min} \mathrm{CO}, 1.1 \mathrm{~g} / \mathrm{min}$ steam, and $1.5 \mathrm{NL} / \mathrm{min} \mathrm{N}_{2}$, was fed continuously until the concentrations of unconverted fuel gas in exit stream increased rapidly. The OC loading for each test was $300.0 \mathrm{~g}$, which formed a packed bed $>150 \mathrm{~mm}$.

In the coal char-fueled CLC experiments, $150.0 \mathrm{~g}$ OC was loaded, fluidized with $\mathrm{N}_{2}$ and then heated to $950{ }^{\circ} \mathrm{C}$. Gasification agent $\left(1.5 \mathrm{~g} / \mathrm{min}\right.$ steam carried by $\left.2.0 \mathrm{NL} / \mathrm{min} \mathrm{N}_{2}\right)$ was introduced to the reactor when the temperature stabilized. Five minutes later, $1.0 \mathrm{~g}$ coal char was fed into the hot bed material to start the reduction.

The stability and integrity of the selected OCs were determined by a 20-cycle CLC experiments. The reduction of each cycle followed the same procedure described above. The reduced OC samples were then fully re-oxidized with $10 \% \mathrm{O}_{2}$. Between the oxidation and reduction periods, the reactor was purged with $4.0 \mathrm{NL} / \mathrm{min}_{2}$ flow. After 20 cycles, the used OCs were cooled to ambient temperature for sampling and characterization. 


\subsection{Data evaluation}

The behavior of OC reduction was analyzed by the mass-based conversion $\left(X_{\mathrm{OC}}\right)$ from TGA. The oxygen transport capacity $\left(\Delta X_{\mathrm{OC}}\right)$ is the maximum percentage of mass loss due to oxygen transfer under experimental conditions. They are calculated by

$$
\begin{aligned}
X_{\mathrm{OC}} & =\frac{m}{m_{\mathrm{ox}}} \\
\Delta X_{\mathrm{OC}} & =\frac{m_{\mathrm{ox}}-m_{\mathrm{red}}}{m_{\mathrm{ox}}}
\end{aligned}
$$

Where $m$ is the mass of the OC during reduction, $m_{\mathrm{ox}}$ is the mass in its full oxidized form, and $m_{\mathrm{red}}$ is the mass of the reduced form obtained under experimental conditions. The oxygen transfer rate, $r_{\mathrm{OC}}$ is defined as the mass-based conversion per unit time $\left(r_{\mathrm{OC}}=d X_{\mathrm{OC}} / d t, \% / \mathrm{min}\right)$.

The instantaneous rate of carbon conversion is used to evaluate the in-situ gasification in CLC, given by

$$
r_{\mathrm{C}}=\frac{d X_{\mathrm{C}} / d t}{1-X_{\mathrm{C}}}
$$

Where $X_{\mathrm{C}}$ is the carbon conversion calculated by

$$
X_{\mathrm{C}}=\frac{m_{\mathrm{C}}(t)}{m_{\text {total }}}
$$

Where $m_{\text {total }}$ is the total mass of carbon introduced to the reactor, $m_{\mathrm{C}}(t)$ is the total mass of carbon in fuel char converted to gas at time of $t$.

From the gas product distribution of the fixed bed reactor, it is possible to calculate the instantaneous syngas conversion rate and OC conversion. The instantaneous selectivity is used [11]

$$
S_{s y n}=1-\frac{0.5 f_{C O}+0.5 f_{\mathrm{H}_{2}}}{f_{\mathrm{CO}_{2}}+0.5 f_{\mathrm{CO}}+0.5 f_{\mathrm{H}_{2}}}
$$

Here $f_{\mathrm{i}}$ is the volumetric fraction of $i$ gas component. Eq. (5) is also applied to calculate the combustion efficiency of intermediate syngas in the solid-fueled CLC, $\eta_{\text {syn }}$.

The OCs, or its reduced form, may catalyze the WGSR in the FR, and influence the final flue gas composition. The OCs' catalytic function for the WGSR is evaluated via the quotient of reaction, $J$, to describe the extent of this reaction as it approaches equilibrium under experimental conditions.

$$
J=\frac{P_{C O 2} P_{H 2}}{P_{C O} P_{H 2 O}}
$$

Where $P_{\mathrm{i}}$ is the integral partial pressure of syngas component at the outlet of the reactor (before steam removal). It is calculated by the integrating the mole flow rate of gas component over the reduction period.

\section{Results and discussion}

\subsection{Oxygen transport of OCs with steam in the syngas}

The oxygen transport behavior of OCs plays an important role in the improvement of in-situ gasification of CLC. Fig. 1 (a)-(d) shows the value of $X_{\mathrm{OC}}$ when the ilmenite-based OCs were reduced with wet syngas in the TGA apparatus. The results of Activated-I reduction with dry gas fuel $\left(20 \mathrm{ml} / \mathrm{min} \mathrm{CO}\right.$ or $\mathrm{H}_{2}$ in $180 \mathrm{ml} / \mathrm{min} \mathrm{Ar}$ ) are shown to illustrate the effect of steam in the fuel gas. In the FR, steam is the essential component bathing OC particles. However, the presence of steam reduced the oxygen transport capacity of Activated-I from $16 \mathrm{wt} . \%$ (for dry fuels) to $3.4 \mathrm{wt} . \%$. The reduction was significantly slowed 
by the reverse oxidation of the reduced OC with steam. Based on these results, wet syngas was used in this study to evaluate the oxygen transport behaviors for all OCs.

The oxygen transport of the FG-I was significantly lower than Activated-I, implying that this OC suffered a great structural change due to granulation. Because both OC's have the same chemical composition, the values of $\Delta X_{\mathrm{OC}}$ were very close to one another. Different from the Activated-I and FG-I, the reduction of two K-added ilmenite OCs was composed of a fast oxygen transfer stage followed by a second slow stage. The fast stage accounted for about $85 \%$ and $80 \%$ of $\Delta X_{\mathrm{OC}}$ for $\mathrm{SK}_{2} \mathrm{O}(5)-\mathrm{I}$ and FG-I- $\mathrm{K}_{2} \mathrm{O}$ (5), respectively. The coating of $\mathrm{K}$ appears to reduce the resistance of lattice oxygen transfer on the particle surface. Therefore, the reduction rate of $\mathrm{SK}_{2} \mathrm{O}(5)$-I in the fast stage was higher than Activated-I. The addition of $\mathrm{K}$ to the interior of the FG OC appears to improve the transfer rate of lattice oxygen from the interior to the surface. In the fast oxygen transfer stage of FG-I- $\mathrm{K}_{2} \mathrm{O}(5)\left(X_{\mathrm{OC}}>97.2 \%\right)$, the value of $r_{\mathrm{OC}}$ was 3.0 times higher than the FG-I. Because granulation is detrimental to the reaction, the enhanced rate of oxygen transfer for FG-I- $\mathrm{K}_{2} \mathrm{O}(5)$ does not originate from granulation but from the addition of $\mathrm{K}$. The addition of $\mathrm{Ca}$ led to very similar oxygen transfer behavior as the FG-I in the first $90 \mathrm{~min}$, but reduced the oxygen transport capacity.

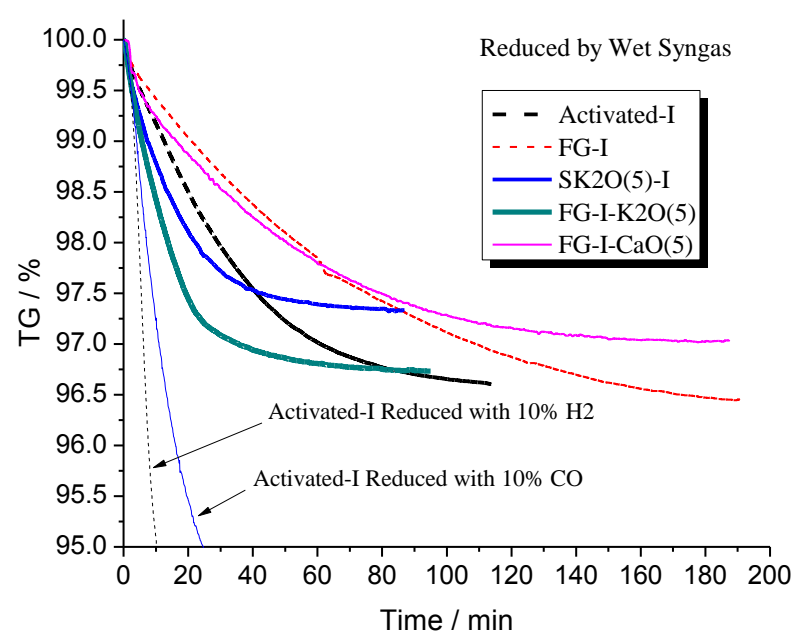

(a) K-and Ca-added ilmenite-based OCs

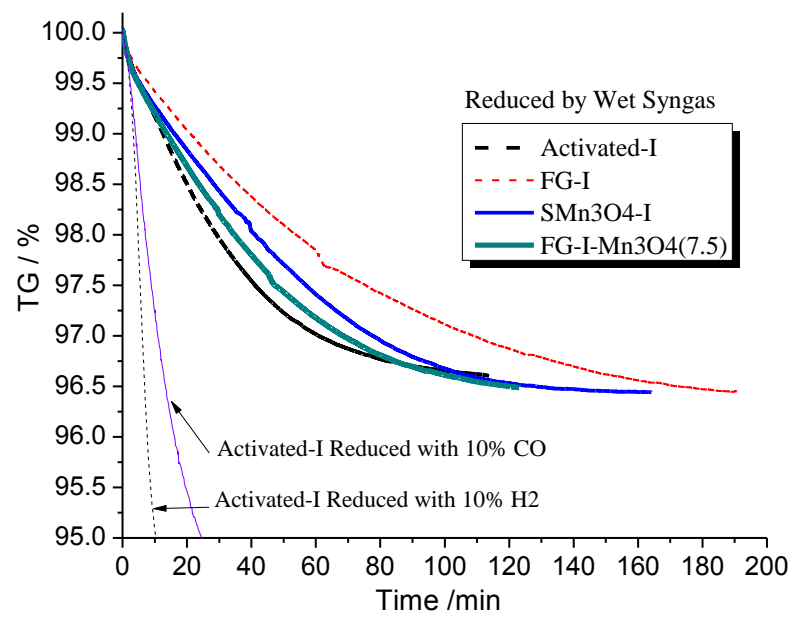

(c) Mn-added ilmenite-based OCs

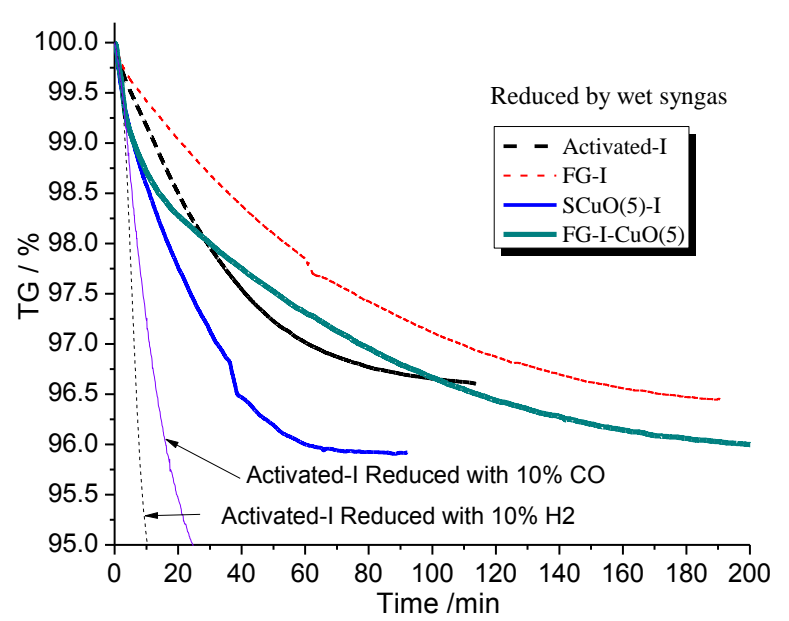

(b) $\mathrm{Cu}$-added ilmenite-based OCs

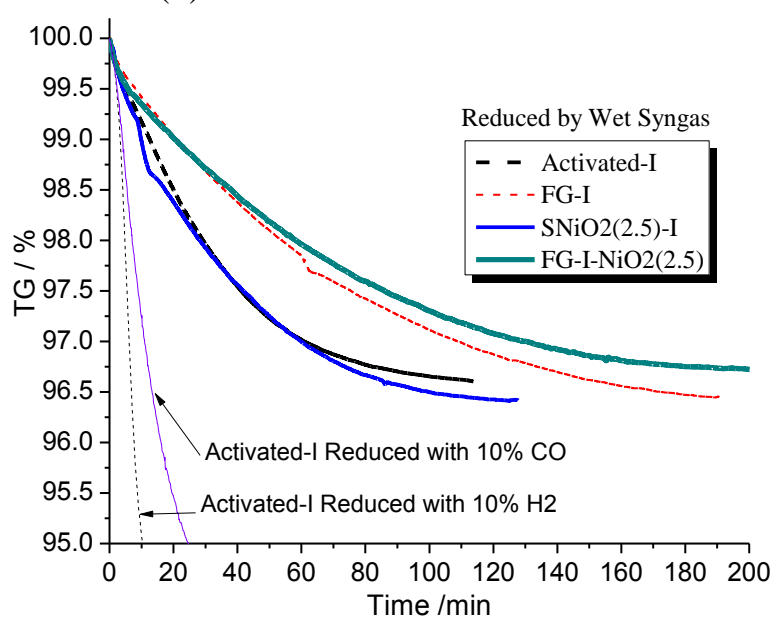

(d) Ni-added ilmenite-based OCs

Fig. $1 X_{\mathrm{OC}}$ of different ilmenite-based OCs obtained with TGA 
Oxygen transport behaviors of these OCs with the addition of $\mathrm{Cu}, \mathrm{Mn}$, and $\mathrm{Ni}$, are presented in Fig. 2(b)(d). The addition of $\mathrm{Cu}$ enhanced the oxygen transport rate and capacity, while the addition of $\mathrm{Mn}$ and $\mathrm{Ni}$ had little effect on the final transport capacity. $\mathrm{SNiO}_{2}(2.5)$-I showed a similar reduction behavior to Activated-I, while the other OCs with $\mathrm{Mn}$ and Ni showed lower oxygen transfer rate than Activated-I. $\mathrm{SCuO}$ (5)-I performed best among the transition-metal-added OCs. However, the degrees of reduction of the ilmenite ore in SCuO (5)-I was not increased as compare to Activated-I. If SCuO (5)-I is considered as a physical mixture, containing $95 \%$ ilmenite and $5 \% \mathrm{CuO}$, the theoretical value of $\Delta X_{\mathrm{OC}}$ in the wet syngas is $4.23 \%$, which very close to the experimental data $\left(\Delta X_{\mathrm{OC}}=4.14 \%\right.$ for SCuO (5)-I). The oxygen uncoupling effect (CLOU) [24] was not seen during the heating of SCuO (5)-I in the TGA experiments. During the two stage-reductions, the fast reduction stage (the first $55 \mathrm{~min}$ ) accounted for $97 \%$ of $\Delta X_{\mathrm{OC}}$. The small amount of highly reducible $\mathrm{Cu}$-Ti-O compounds $\left(\mathrm{Cu}_{3} \mathrm{TiO}_{4}\right)$ in the OCs [25-26] is not enough to explain the significant increase of reduction rate. Because the oxidation of $\mathrm{Cu}_{2} \mathrm{O}$ or $\mathrm{Cu}$ with steam is not spontaneous at high temperature [27], $\mathrm{Cu}$-element on the surface of particles significantly lowers the reverse oxidation of the reduced OC by steam, which led to a higher reduction rate compared to Activated-I OC.

\subsection{Selectivity of OCs in converting syngas to $\mathrm{CO}_{2}$ and $\mathrm{H}_{2} \mathrm{O}$}

A preferable $\mathrm{OC}$ is expected to retain an adequate ability to convert syngas to $\mathrm{CO}_{2}$ or $\mathrm{H}_{2} \mathrm{O}$ across a wide range of oxygen loss ratio ( $\triangle X_{\mathrm{OC}}$ ', the amount of oxygen transferred to fuels/total mass of OC). The OC selectivity obtained in the fixed bed reactor is presented in Fig. 2. Because of the thermodynamics and channel flow, the value of $S_{\text {syn }}$ was always lower than 1.0. For Activated-I, 0.98 of $S_{\text {syn }}$ was achieved until $\triangle X_{\mathrm{OC}}$ ' was higher than 0.04 . This value was approximate to the thermodynamics $\left(0.995\right.$ at $\left.950{ }^{\circ} \mathrm{C}\right)$ when $\mathrm{Fe}_{2} \mathrm{TiO}_{5}$ in Activated-I is reduced to $\mathrm{FeTiO}_{3}$ [9]. According to the chemical composition analysis, Activated-I consisted reasonably of 79.3 wt. $\% \mathrm{Fe}_{2} \mathrm{TiO}_{5}, 7.37 \mathrm{wt} \% \mathrm{TiO}_{2}$, and 13.33 wt. \% inert materials (including $\mathrm{SiO}_{2}, \mathrm{Al}_{2} \mathrm{O}_{3}$, and $\mathrm{MgO}$ ). Therefore, the reduction of Activated-I would lead to oxygen loss rate of 0.0396 , which is consistent with the experimental value. The selectivity of FG-I at steady reaction conditions was approximately 10 percentage points lower than the Activated-I, indicating strong detrimental impact of granulation. When $\Delta X_{\mathrm{OC}}{ }^{\prime}<0.035$, FG-I- $\mathrm{K}_{2} \mathrm{O}$ (5) and $\mathrm{SK}_{2} \mathrm{O}$ (5)-I showed a similar

value of $S_{\mathrm{syn}}$ as the Activated-I. The value of $S_{\mathrm{syn}}$ for FG-I-CaO(5) was quite high at the beginning of the reaction, but declined quickly as the reaction occurred.

$\mathrm{SCuO}(5)-\mathrm{I}$ and FG-I-CuO(5) showed better selectivity than Activated-I, with 0.98-0.99 $S_{\text {syn }}$ until $\Delta X_{\mathrm{OC}}$ was less than 0.05 . The addition of $\mathrm{Cu}$ increased the oxygen transport capacity with high fuel conversion. The synergetic effects to improve oxygen transport capacity with high fuel conversion have been observed when copper is coated on manganese ore or Hematite [28-29]. In these studies, oxygen transport capacity with high selectivity was dramatically enhanced six times. However, in this study, the increased oxygen transport capacity with high fuel conversion was solely attributed to the reduction of the $\mathrm{CuO}$ phase added to the OCs. The OCs added with $\mathrm{Mn}$ - and Ni- elements performed poorly compared to the Activated-I. Agglomeration occurred for $\mathrm{SMn}_{3} \mathrm{O}_{4}(7.5)$-I, which resulted in a rapid decrease in selectivity as $\Delta X_{\mathrm{OC}}{ }^{\prime}$ was higher than 0.02 . 

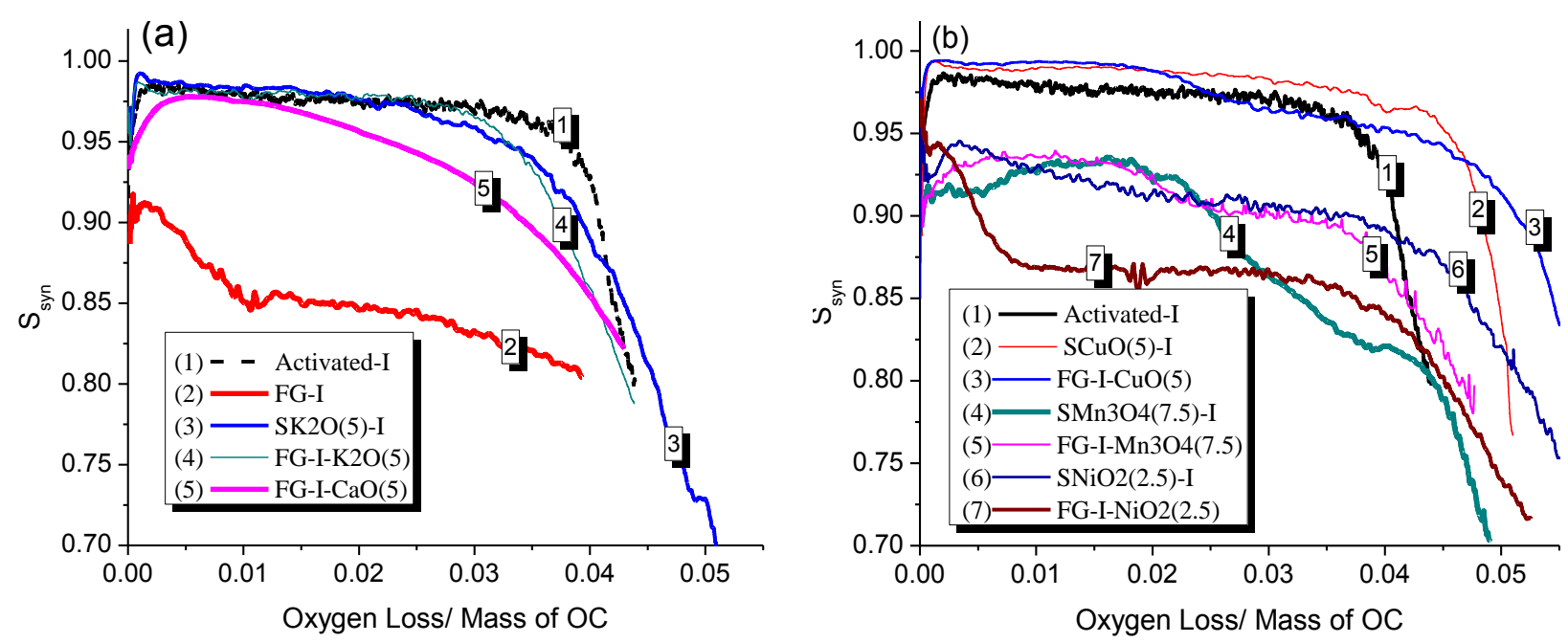

Fig. 2 Selectivity of ilmenite-based OCs (a) K-and Ca-added, (b) $\mathrm{Cu}-, \mathrm{Mn}$ - and Ni- added

\subsection{In-situ gasification and combustion efficiency in coal-char fueled CLC}

Comprehensive testing of the coal char-fueled CLC was performed for all of the OCs, with their instantaneous rate of carbon conversion presented in Fig. 3. Representative gas concentration profiles are included in the supporting materials, S-Fig. 1. In order to avoid the introduction of errors at the beginning and the end of reaction, the value of $X_{\mathrm{C}}$ between 0.1- 0.8 was used as the representative of steady reaction. For comparison, the results for external gasification are also presented in Fig. 3 (a). In external gasification, $250.0 \mathrm{~g}$ sand $(125-355 \mu \mathrm{m})$ was used as the bed material, while the other conditions and procedure remained the same as the CLC experiments. Compared to the external gasification, the CLC experiment using Activated-I and FG-I improved the gasification rate by 35\%. Among the transition metal-added OCs, SCuO(5)-I performed best, with > 100\% improvement in char gasification rate compared to the external gasification experiment. Compared to other OCs, $\mathrm{SK}_{2} \mathrm{O}(5)-\mathrm{I}$ and FG-I- $\mathrm{K}_{2} \mathrm{O}(5)$ significantly improved the gasification rate, and the values of $r_{\mathrm{C}}$ exhibited much higher increasing rate. These results indicate that either the char underwent a violent structural break-up or became more reactive during gasification.

Fig. 4 shows the combustion efficiencies for the same CLC experiments in Fig. 3. With the exception of FG-I and FG-I-NiO 2 (2.5), all other OCs demonstrated stable combustion efficiency over the reduction period. Approximately 0.95 of $\eta_{\text {syn }}$ was obtained for $\mathrm{SK}_{2} \mathrm{O}(5)-\mathrm{I}$, FG-I- $\mathrm{K}_{2} \mathrm{O}(5)$, and $\mathrm{SCuO}(5)-\mathrm{I}$ OCs. For FG-I and FG-I-NiO (2.5) OCs, $\eta_{\text {syn }}$ varied between $0.65-0.70$ at steady reaction conditions. These results indicate that the two OCs were not well suited for coal-fueled CLC. All other OCs, including FG-I$\mathrm{CaO}(5)$, FG-I-CuO(5), $\mathrm{SMn}_{3} \mathrm{O}_{4}(7.5)-\mathrm{I}$, FG-I-Mn $\mathrm{Mn}_{4}(7.5)$ and $\mathrm{SNiO}_{2}(2.5)-\mathrm{I}$ had combustion efficiencies similar to Activated-I. 

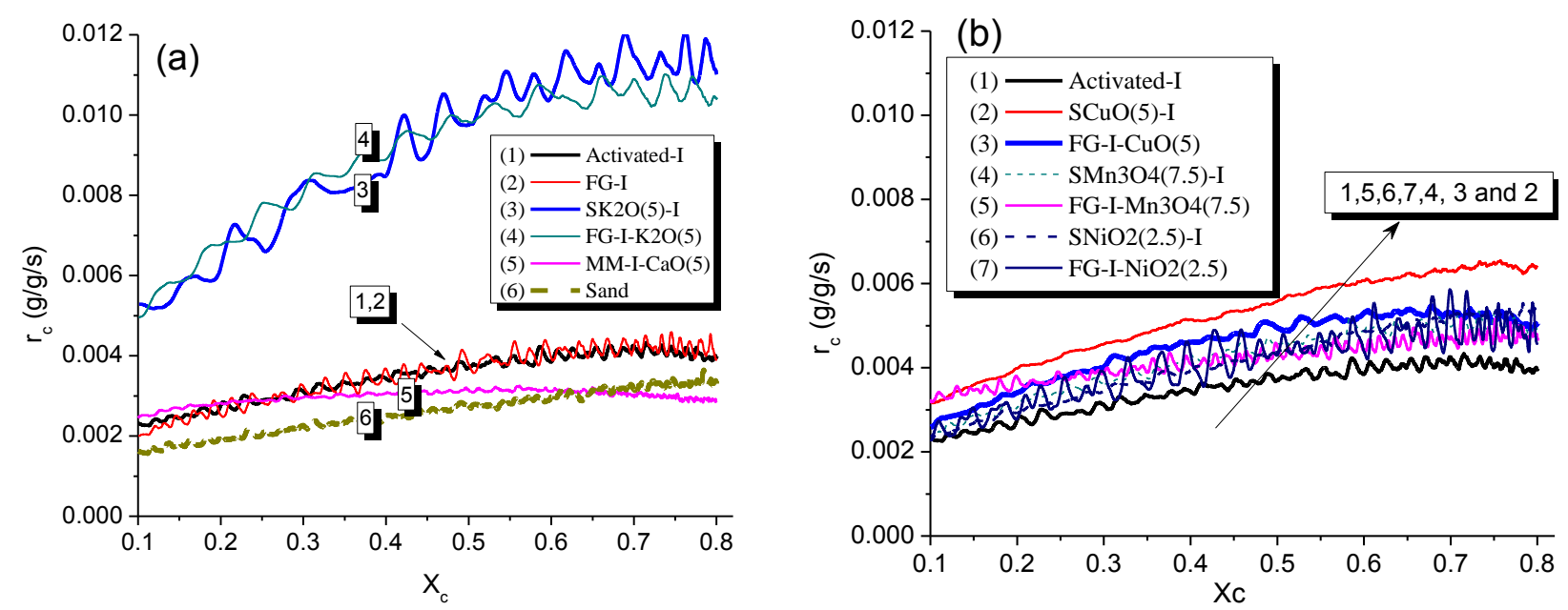

Fig. 3 Instantaneous rate of carbon conversion in CLC experiments using different ilmenite-based OCs:

(a) K- and $\mathrm{Ca}$-added, (b) $\mathrm{Cu}$-, $\mathrm{Mn}$ - and $\mathrm{Ni}$ - added.
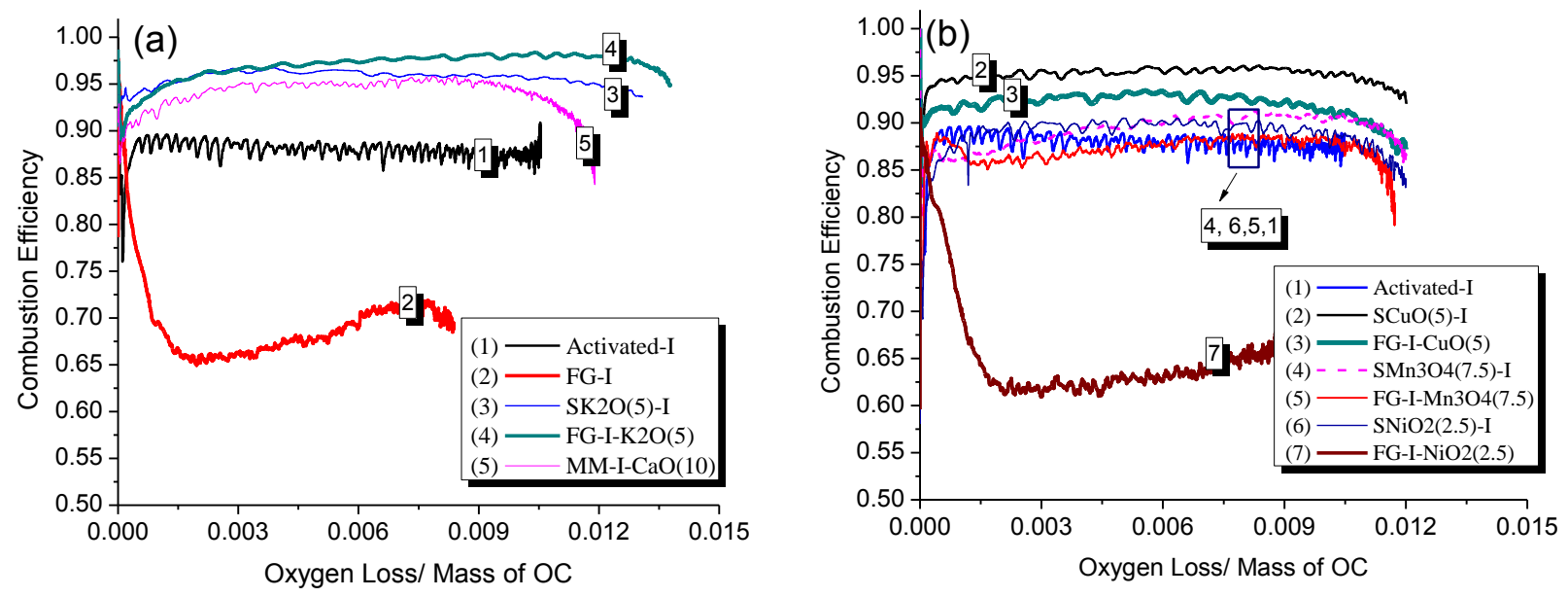

Fig. 4 Combustion efficiency of CLC experiments using different ilmenite-based OCs: (a) K- and Caadded, (b) $\mathrm{Cu}-, \mathrm{Mn}$ - and $\mathrm{Ni}$ - added.

\subsection{Performances OCs in multi-redox cycles}

Three samples, $\mathrm{SK}_{2} \mathrm{O}$ (5)-I, FG-I- $\mathrm{K}_{2} \mathrm{O}$ (5), and $\mathrm{SCuO}(5)-\mathrm{I}$, showed the most desirable performance. So these samples were selected for further study and subjected to 20 redox cycle of CLC experiments for better understand their behaviors in long-term operation. The OC's performance changes with redox cycle, and can be represented by the average carbon conversion rate $\left(r_{\mathrm{C}}^{-}\right)$and combustion efficiency $\left({ }_{\eta_{\mathrm{syn}}}^{-}\right)$during consecutive reduction. These results, along with that of the Activated-I, are shown in Fig. 5. The values of $\bar{r}_{\mathrm{C}}^{-}$and $\eta_{\mathrm{syn}}^{-}$were collected when $X_{\mathrm{C}}$ varied between 0.1-0.8. The results showed that the reactivity of the modified OCs with coal char were roughly stable over 20 redox cycles. After each cycle, the OC was fully regenerated, and this regeneration contributed to combusting a high percentage of carbon and maintaining their high reactivity. A slight activation process was observed for Activated-I in the first 5 cycles, and the OC's reactivity was maintained thereafter. It is obvious that the structure of the starting materials were not well stabilized even after 5 redox cycles with gaseous fuel. Here, the natural activation of the ilmenite $\mathrm{OC}$, due to $\mathrm{Fe}_{2} \mathrm{O}_{3}$ segregating from $\mathrm{Fe}_{2} \mathrm{TiO}_{5}$, occurred at the cost of oxygen transport 
capacity during the redox cycle [9]. Furthermore, the value of $\eta_{\text {syn }}^{-}$for Activated-I slightly increased from 0.88 to 0.90 after 20 cycles. Less activation was observed for SCuO (5)-I during 20 cycles. As will be shown, the formation of $\mathrm{Cu}-\mathrm{Ti}-\mathrm{O}$ compound on the particle surface improved the OC's reactivity and the physical stability. The value of $\eta_{\text {syn }}^{-}$for SCuO (5)-I was improved by 2.0 percentage points during the first five cycles, and remained constant at 0.97 during subsequent cycles. The average combustion efficiency of $\mathrm{SK}_{2} \mathrm{O}$ (5)-I and FG-I- $\mathrm{K}_{2} \mathrm{O}$ (5) increased to 0.98 after 20 cycles. Considering high combustion efficiency was realized for these two fresh samples $\left(\mathrm{SK}_{2} \mathrm{O}\right.$ (5)-I and FG-I- $\mathrm{K}_{2} \mathrm{O}$ (5)), this increase should be a substantial improvement. Here, the increase in combustion efficiency may be due to their modified thermodynamics during consecutive cycle.
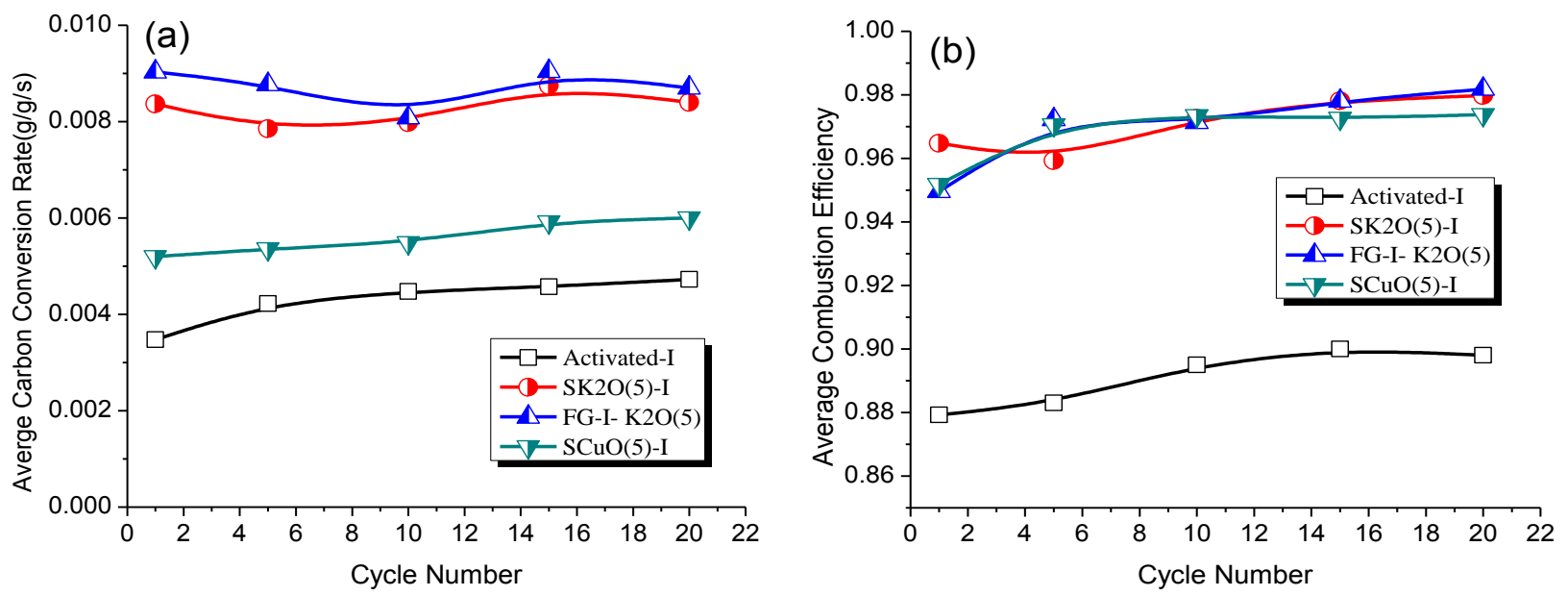

Fig. 5 Cyclic performances of the selected OCs in CLC experiments: (a) average carbon conversion rate, (b) average combustion efficiency

\subsection{Discussion}

\subsubsection{Potential in improvement of gasification rate and combustion efficiency}

The chemical processes in the FR are char gasification, OC reduction and the WGSR. Coal char is first gasified into an intermediate syngas containing $\mathrm{CO}, \mathrm{H}_{2}$ and $\mathrm{CO}_{2}$. These reducing components are simultaneously converted to $\mathrm{CO}_{2}$ and $\mathrm{H}_{2} \mathrm{O}$ by OCs surrounding the coal char particles. The gasification rate is improved with lowered inhibition of $\mathrm{CO}$ and $\mathrm{H}_{2}$ as these gases are quickly oxidized by the OCs [30]. According to this reaction regime, the gasification rate can be correlated to the OC's reactivity. As shown in Fig. 6, the value of ${ }_{r_{\mathrm{C}}}^{-}$from different CLC experiments were plotted against the average OC reduction rates obtained from the TGA apparatus. Here, the average OC reduction rates $\left({ }_{\mathrm{OCC}^{-}}^{-}\right)$are timeaveraged during the initial reduction period corresponding to $X_{\mathrm{OC}}=0.985-1.0$. This is because the theoretical oxygen consumption for full fuel combustion in CLC experiment yields approximately $1.5 \%$ of OC weight loss. The result of external gasification was given under the assumption that sand was absent of lattice oxygen for fuel combustion. With the exception of $\mathrm{SK}_{2} \mathrm{O}$ (5)-I and FG-I- $\mathrm{K}_{2} \mathrm{O}$ (5), there is a clear trend of increasing $r_{\mathrm{C}}^{-}$with $r_{\mathrm{OC}}^{-}$for all of the other OCs. So $\bar{r}_{\mathrm{C}}^{-}$is related to ${ }_{\mathrm{OC}_{\mathrm{OC}}}$ via a linear relationship 


$$
r_{C}=a+b \cdot r_{O C}^{-}
$$

Where $a$ and $b$ represent ${ }_{r_{\mathrm{C}}}$ of the external gasification and the fitting linear rate constant, which were estimated as 0.00259 and 0.0195 , respectively for this study. Eq. (7) reveals how the OCs' reduction reactivity influences the in-situ gasification of CLC if the above reaction regime is followed. Obviously, the values of $a$ and $b$ depend on the type of coal char and OCs.

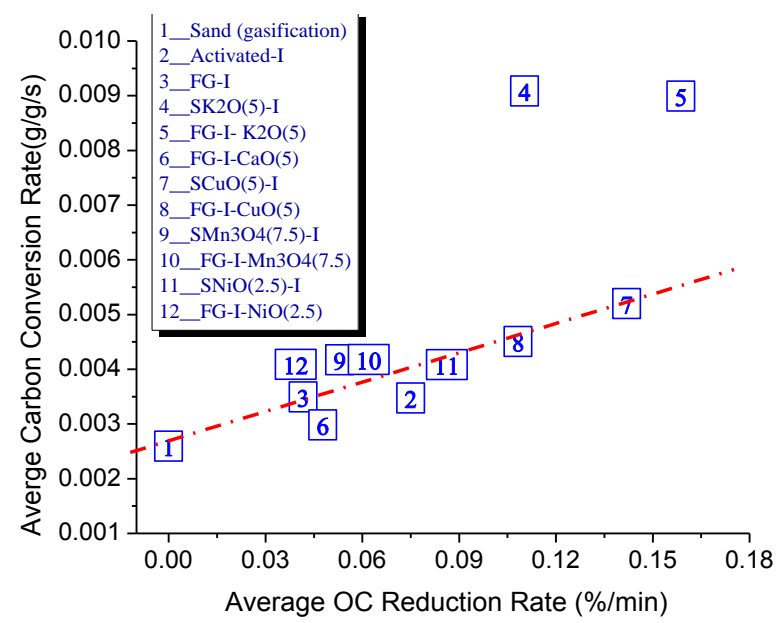

Fig. 6 Correlation between the average carbon conversion rates in CLC experiment and average $\mathrm{OC}$ reduction rate obtained from the TGA.

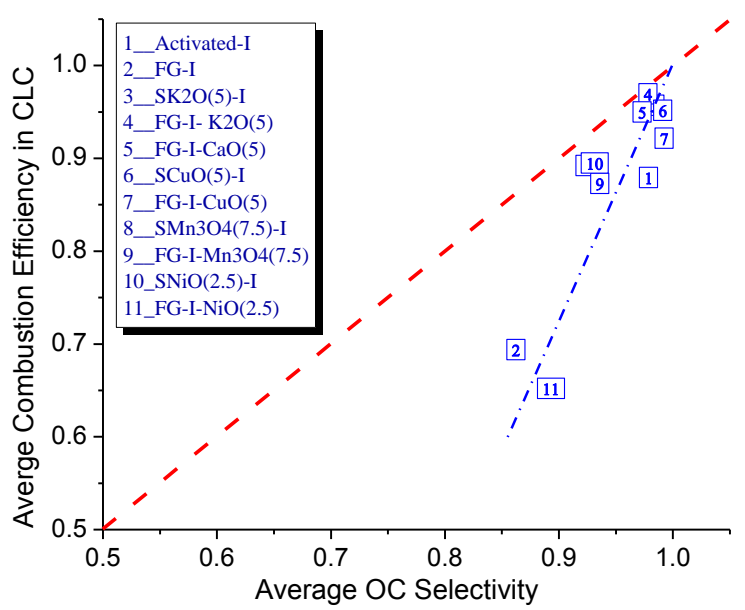

Fig. 7 Correlation between the average combustion efficiency in CLC experiments and the average selectivity from the fixed bed reactor

A large deviation of the K-added OCs from the functionality (Eq. (7)) suggests a different mechanism is involved during coal char gasification. The high reduction reactivity of the K-added OCs only explains part of the improved in-situ gasification. However, as indicated by the data points of 4 and 5 (Fig. 6), the increased OC reduction rate could not account for all the increment of gasification rate.

The value of $\eta_{\mathrm{syn}}$ for different CLC experiments compared to the average selectivity obtained from the fixed bed reactor, are presented in Fig. 7. This plot illustrates how the OC's selectivity influences the intermediate syngas conversion in CLC under the fluidization regime. The general trend showed that the difference between $\eta_{\text {syn }}^{-}$and $S_{\text {syn }}^{-}$increases rapidly as $S_{\text {syn }}^{-}$decreases. The best performing OCs $\left(\mathrm{SK}_{2} \mathrm{O}(5)-\mathrm{I}\right.$, FG-I- $\mathrm{K}_{2} \mathrm{O}(5)$ and $\left.\mathrm{SCuO}(5)-\mathrm{I}\right)$ possess a selectivity $>0.98$, and $\left(S_{\mathrm{syn}}^{-}-\eta_{\mathrm{syn}}^{-}\right)$of $0.02-0.03$. When $S_{\mathrm{syn}}^{-}$was lower than 0.90, the value of $\left(S_{\mathrm{syn}}^{-}-\eta_{\mathrm{syn}}^{-}\right)$increased rapidly to approximate 0.20 . The value of $S_{\mathrm{syn}}^{-}$obtained from the fixed bed reactor, reflects the syngas conversion under ideal conditions. Under these conditions, wet syngas are gradually converted as it moves across the bed, and this allows the syngas have enough time to react with the OCs. The value of $\eta_{\text {syn }}^{-}$from the CLC experiments describes the intermediate syngas conversion where the reaction between the two solids (coal char and OCs) occurs via the phase transfer of intermediate gas. Thus, the value of $\left(S_{\mathrm{syn}}^{-}-\eta_{\mathrm{syn}}^{-}\right)$, to a large extent, describes the extent of incomplete gas 
phase transfer between char and the OC. Fig. 7 reveals that the improvement in OC's selectivity significantly diminish the impact of the incomplete gas phase transfer in CLC.

\subsubsection{Possible solid-solid reaction between OCs and coal char}

The direct solid-solid reaction between $\mathrm{OC}$ and coal char, or the catalyzed char gasification arising from the addition of $\mathrm{K}$, possibly make contributions to the promoted gasification of CLC when $\mathrm{SK}_{2} \mathrm{O}$ (5)-I or FG-I- $\mathrm{K}_{2} \mathrm{O}(5)$ was used as OCs. During the catalyzed gasification mechanism, potassium elements in OCs are gradually vaporized at high temperature, and deposit on the surface of the char to catalyze gasification [7]. If this is the case, the potassium concentration of the OCs should decrease during operation. However, compare to the fresh sample, the used OCs after 20 redox cycles do not show observable loss of potassium fraction. So the catalyzed gasification mechanism can be excluded in this study. For the $\mathrm{SCuO}$ (5)-I, gasification could be improved by the oxygen uncoupling effects where lattice oxygen is released into the gas phase to react with the solid fuel [31]. The CLC experiment revealed that oxygen concentration in sweeping gas during the inert period of CLC was not as high as expected when $\mathrm{SCuO}$ (5)-I was used as OCs. Based on these results, the pathway of oxygen uncoupling was also excluded.

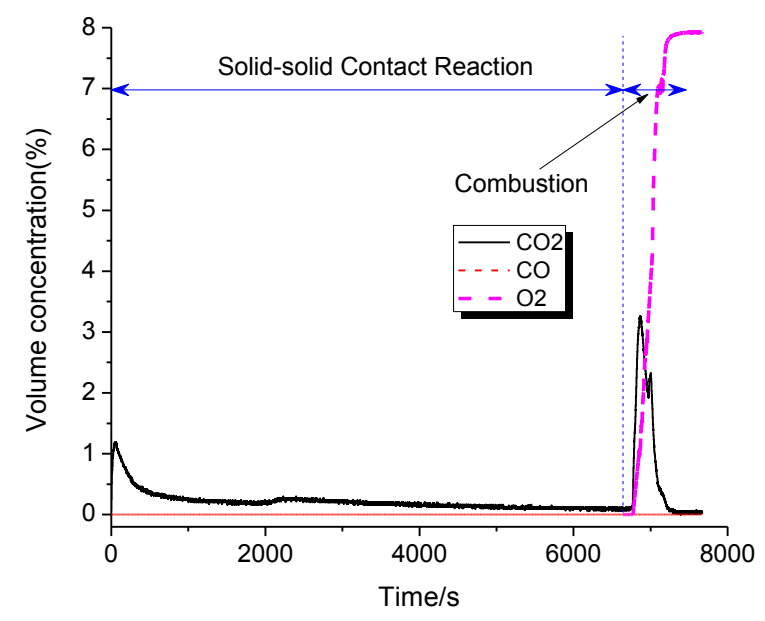

Fig. 8 Gas concentration profile during the experiment of solid-solid reaction between PRB coal char and $\mathrm{SCuO}(5)-\mathrm{I}$.

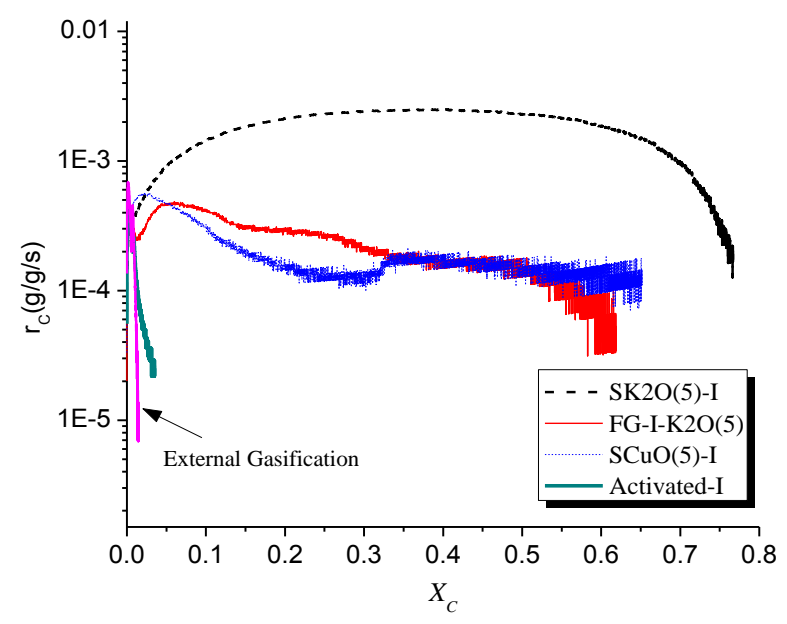

Fig. 9 Coal char conversion rate due to the solid-solid contact reaction between PRB char and different OCs.

A series of tests was performed to validate the role of the solid-solid reaction between OCs and coal char during in-situ gasification of CLC. Sand, Activated-I, $\mathrm{SK}_{2} \mathrm{O}$ (5)-I, FG-I- $\mathrm{K}_{2} \mathrm{O}$ (5), and SCuO (5)-I were selected for further study. The operational conditions remained the same as the CLC experiment, with the exception of fluidization gas, which was composed of only $4.0 \mathrm{NL} / \mathrm{min}_{2}$ in the experiment of solid-solid reaction. When sand or Activated-I was used as bed materials, a very small amount of carbon-containing gas were observed during the initial char devolatilization $(<45 \mathrm{~s})$. However, after this period, no carboncontaining gas was present in the exiting gas, indicating the absence of the solid-solid reaction. The experiment using $\mathrm{SK}_{2} \mathrm{O}(5)-\mathrm{I}$, FG-I- $\mathrm{K}_{2} \mathrm{O}(5)$, or $\mathrm{SCuO}(5)-\mathrm{I}$, experienced an appreciable amount of coal char oxidation in the $\mathrm{N}_{2}$ stream, with only $\mathrm{CO}_{2}$ present in the exit gas. This observation is a manifestation of the direct solid-solid reaction between OC and coal char [24]. As an example, Fig. 8 shows the gas concentration profile during the solid-solid reaction between coal char and SCuO (5)-I. Fig. 9 shows the instantaneous rate of carbon conversion from the solid-solid reaction for different bed materials. Compared to in-situ gasification in CLC, the solid-solid reaction between $\mathrm{SK}_{2} \mathrm{O}$ (5)-I, FG-I- $\mathrm{K}_{2} \mathrm{O}$ (5), or 
$\mathrm{SCuO}$ (5)-I and coal char was slow, but proceeds to a high level of carbon conversion. The relative reaction rate at a given carbon conversion ( $\alpha$ - the ratio of the carbon conversion rate due to the solid-solid reaction to that of CLC) can be used to describe the role of the solid-solid reaction (the detailed definition can be found elsewhere [24]). Using this calculation, the average value of $\alpha$, in the range of $X_{\mathrm{C}}=0.1-0.6$, was $3.3 \%$ and $3.2 \%$ for $\mathrm{SCuO}(5)-\mathrm{I} \mathrm{OC}$ and FG-I- $\mathrm{K}_{2} \mathrm{O}$ (5), respectively. Therefore, the contribution of the direct solid-solid reaction in CLC is likely negligible for these two OCs. The average value of $\alpha$ for $\mathrm{SK}_{2} \mathrm{O}$ (5)-I is $28.5 \%$. However, this is not enough to account for the improvement of char gasification. These results indicate that the direct solid-solid reaction is not the sole and determining pathway for the significant improvements of gasification in CLC when $\mathrm{SK}_{2} \mathrm{O}$ (5)-I or FG-I- $\mathrm{K}_{2} \mathrm{O}$ (5) is used.

\subsubsection{Water gas shift reaction}

Due to the thermodynamics and incomplete reaction of CLC, there is a level of unconverted fuel gas in the $\mathrm{CO}_{2} / \mathrm{H}_{2} \mathrm{O}$ stream. In the $\mathrm{FR}$, the WGSR tries to shift the gas components towards the equilibrium of that condition, and the rate of this reaction plays a vital role [32-33]. OC particles in the bed section (or in their reduced form) may catalyze the WGSR. Fig. 10 illustrates the catalytic functions of the most promising OCs during the first and the $20^{\text {th }}$ cycles of the CLC experiments, where the value of $J$ was calculated according to Eq. (6). Fresh Activated-I did not promote the WGSR compared to sand during the external gasification. The used Activated-I in the $20^{\text {th }}$ cycle weakly prompted the $W G S R$, and $\mathrm{Fe}_{3} \mathrm{O}_{4}$ phase created during the redox cycles catalyzed the reaction. The fresh $\mathrm{SK}_{2} \mathrm{O}$ (5)-I showed strong a catalytic effect, with the value of $J(0.53)$ very close to the equilibrium constant at $950{ }^{\circ} \mathrm{C}, K_{\text {eq }}(0.68)$. This meant that the WGSR in the bed zone proceeded rapidly towards equilibrium. Fresh FG-I- $\mathrm{K}_{2} \mathrm{O}$ (5) was less catalytic than fresh $\mathrm{SK}_{2} \mathrm{O}$ (5)-I, but its performances in the $20^{\text {th }}$ cycle was approximate to $\mathrm{SK}_{2} \mathrm{O}$ (5)-I.

The catalyzed in-situ WGSR in the bed zone may play a role in enhancing CLC gasification. The catalyzed in-situ WGSR among the intermediate syngas lowers $\mathrm{CO}$ content and increases the concentration of $\mathrm{H}_{2}$. It allows more $\mathrm{H}_{2}$ to react with the $\mathrm{OCs}$ at higher rate because $\mathrm{H}_{2}$ is the more reactive reducing agent, as shown in Fig. 1. In return, the quick consumption of the gasification inhibitors increased combustion efficiency and the gasification rate. This mechanism is partially confirmed by the fact that CLC experiments of two K'added OCs presented a combination of high gasification rate and strong in-situ WGSR effect.

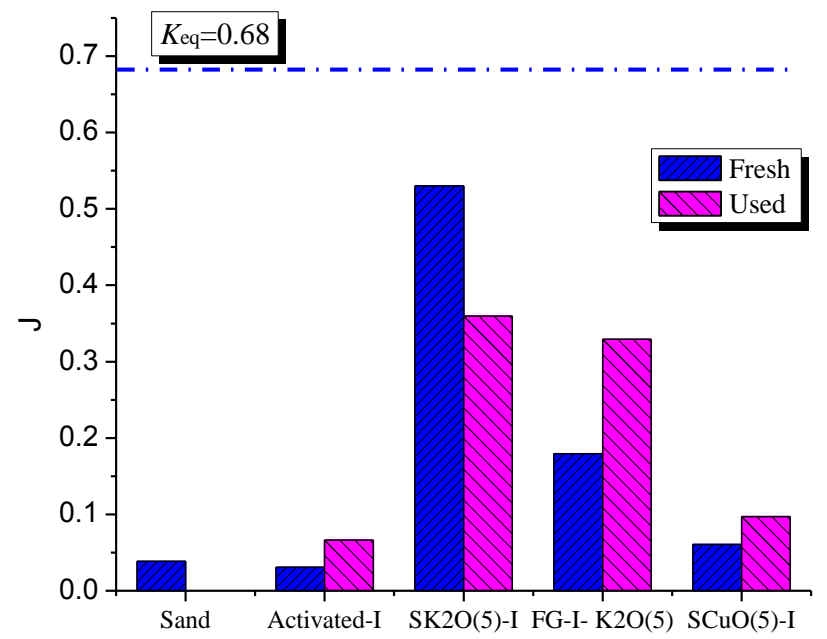

Fig. 10. The values of $J$ during CLC experiments using different OCs (the equilibrium constant of WGSR at $950{ }^{\circ} \mathrm{C}$ was calculated by $\left.\log K_{e q}=-2.4198+0.0003855 T+\frac{2180.6}{T}[34]\right)$. 


\subsubsection{Physical and chemical change during multiple redox cycles}

For the most promising OCs, the decay of $\mathrm{K}$ or $\mathrm{Cu}$ elements, agglomeration or sintering, coal ash contamination, and change in morphology are the major concerns for long term operation. Fig. 11 and Table 4 show the SEM images and chemical compositions for the fresh and used OCs, respectively. The BET surface area, mechanical strength, and XRD analyses are listed in Table 1. The fresh Activated-I possesses a very dense structure (Fig. 11 (a)), and is composed of $\mathrm{Fe}_{2} \mathrm{TiO}_{5}$ and a small amount of $\mathrm{Fe}_{2} \mathrm{O}_{3}$. During 20 redox cycles, Activated-I particles experienced strong rounding and gradual formation of external layer. The formation of the external layer was the result of Fe-element segregation at the surface of the particles from $\mathrm{Fe}_{2} \mathrm{TiO}_{5}$ during reduction [9]. The external layer became Fe-element enriched, while the internal core was Ti-element enriched after 20 redox cycles. Compared to the fresh sample, the used Activated-I had much stronger characterization peaks of $\mathrm{Fe}_{2} \mathrm{O}_{3}$ phase in the XRD spectrum. The external layer of the used sample cracked, and parts of this external layer fell from the internal core. In Fig. 11 (b), a small piece of the external layer (in the right side) detached from the particles and exposed the internal core. The dense external layer was composed primarily Fe-element, and the internal core was composed of high and increasing concentration of Ti-element. Furthermore, the existence of the external layer increased the fragility of the particles.

Compared to the Activated-I, K-added OCs are composed of a considerable amount of free $\mathrm{Fe}_{2} \mathrm{O}_{3}$ crystalline phase and less $\mathrm{Fe}_{2} \mathrm{TiO}_{5}$. K-elements in $\mathrm{SK}_{2} \mathrm{O}$ (5)-I and FG-I-K $\mathrm{K}_{2} \mathrm{O}(5)$ were immobilized as $\mathrm{K}_{2}\left(\mathrm{Ti}_{8} \mathrm{O}_{17}\right)$ and $\mathrm{K}_{1.46} \mathrm{Ti}_{7.2} \mathrm{Fe}_{0.8} \mathrm{O}_{16}$. Over 20 redox cycles, the $\mathrm{K}_{2} \mathrm{O}$ fraction did not decline for the two $\mathrm{K}-$ added OCs, indicating that $\mathrm{K}$ elements in these OCs were quite stable. The addition of K-elements and the abundance of $\mathrm{SiO}_{2}$ in coal ash (see coal ash analysis in Table 3) seem to increase the risk of chemical reaction between OC and coal ash. In Fig.11 (d) and (f), ash-like melted granules were seen on the particle surfaces. Furthermore, $\mathrm{SiO}_{2}$ concentration of the used $\mathrm{SK}_{2} \mathrm{O}$ (5)-I and FG-I- $\mathrm{K}_{2} \mathrm{O}$ (5) increased by $2 \%$ points during this time. The SEM images revealed the coating of the K-element seriously altered the changing trend of particle morphology during multiple redox cycles. For the fresh $\mathrm{SK}_{2} \mathrm{O}(5)-\mathrm{I}$ (Fig. 11 (c)), the granular particles reacted with some of $\mathrm{K}_{2} \mathrm{O}$ and underwent considerable sintering, while the remainder of $\mathrm{K}_{2} \mathrm{O}$ was homogenously distributed on the particle surface. An Fe-rich external shell did not form on the surface of the used $\mathrm{SK}_{2} \mathrm{O}(5)$-I. Instead, the formation of big crystals (1-2 $\left.\mu \mathrm{m}\right)$ and macropores completely reconstructed the surface area of the particles, and as a result, the crushing strength decreased from $4.7 \mathrm{~N}$ to $3.2 \mathrm{~N}$ after 20 cycles.

The $\mathrm{Cu}$-element coating effectively hindered the formation of the external layer due to Fe-element segregation in multiple redox cycle. For fresh $\mathrm{SCuO}$ (5)-I, Cu-elements were evenly distributed on the particle surface. In 20 cycles, the particle surface underwent considerable sintering, and average diameter of the granules increased considerably from $1 \mu \mathrm{m}$ to $5 \mu \mathrm{m}$. SEM-EDX analysis reveals that $\mathrm{Cu}$-, Ti- and Fe-elements were evenly distributed on the used particles (Fig. 11 (h)). $\mathrm{Cu}_{3} \mathrm{TiO}_{4}$, created via the reaction between $\mathrm{CuO}$ and ilmenite during calcination, protected $\mathrm{Fe}_{2} \mathrm{TiO}_{5}$ from direct decomposition to $\mathrm{Fe}_{2} \mathrm{O}_{3}$ and $\mathrm{TiO}_{2}$ during reduction. Compared the fresh sample, the used $\mathrm{SCuO}$ (5)-I particles possessed a very dense structure and maintained high mechanical strength. 


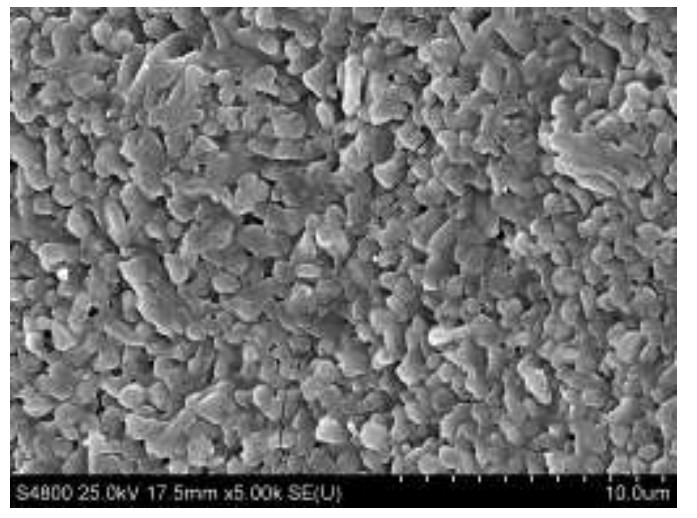

(a) Activated-I (Fresh)

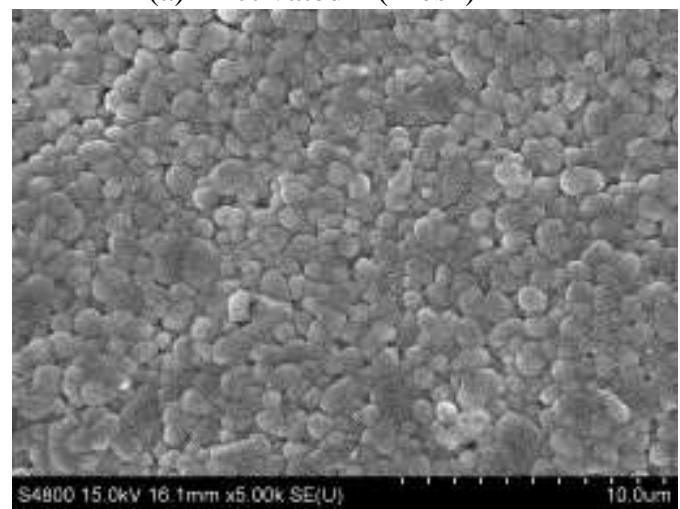

(c) $\mathrm{SK}_{2} \mathrm{O}(5)-\mathrm{I}$ (Fresh)

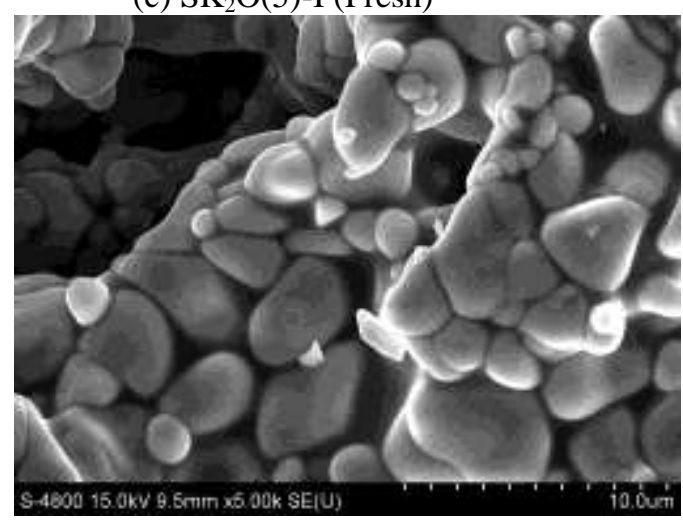

(e) FG-I- $\mathrm{K}_{2} \mathrm{O}(5)$ (Fresh)

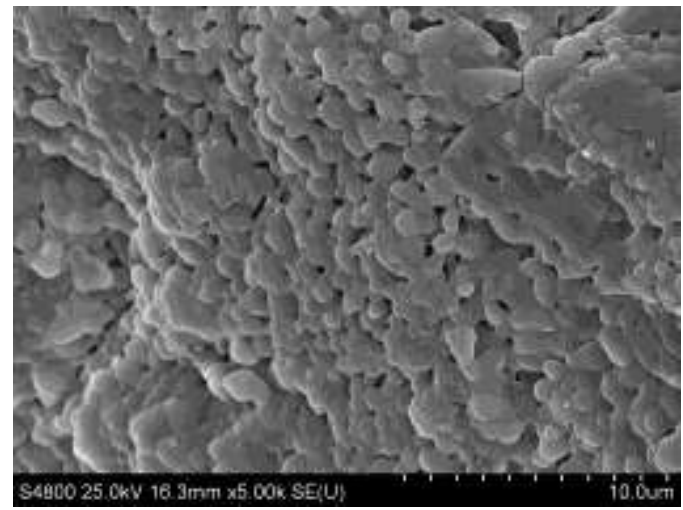

(g) $\mathrm{SCuO}(5)-\mathrm{I}$ (Fresh)

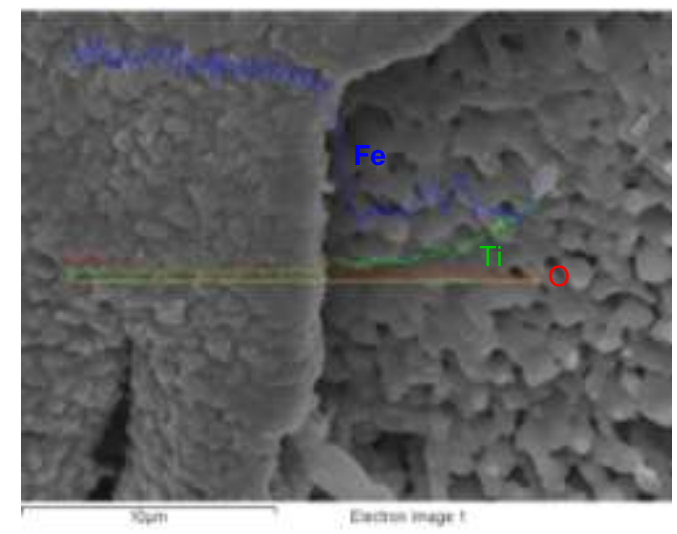

(b) Activated-I (used)

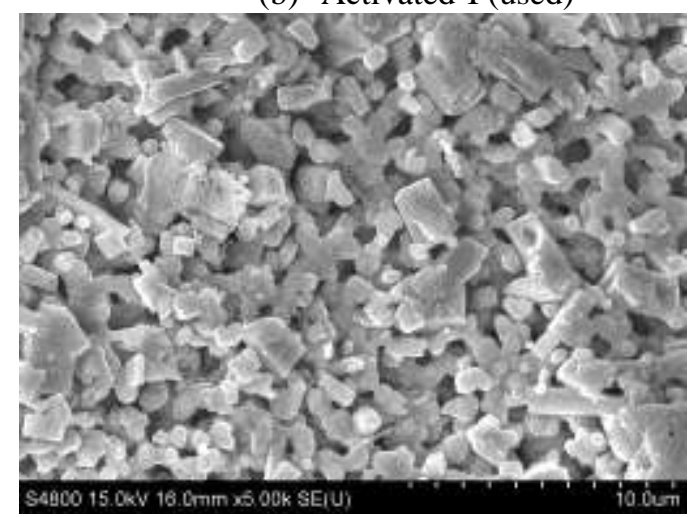

(d) $\mathrm{SK}_{2} \mathrm{O}(5)-\mathrm{I}$ (used)

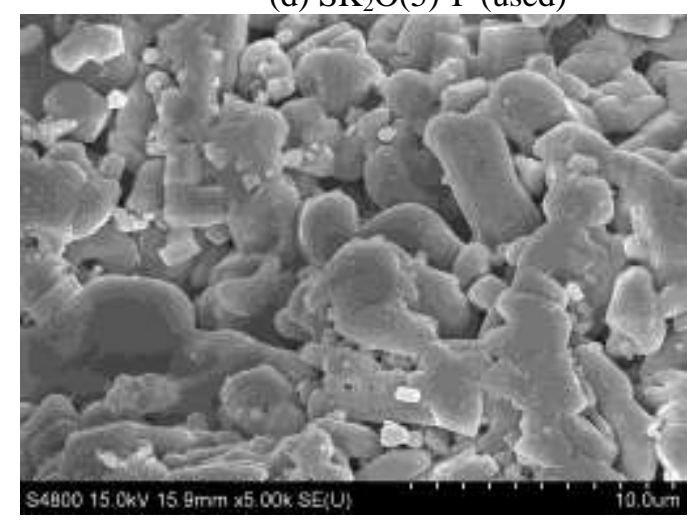

(f) FG-I- $\mathrm{K}_{2} \mathrm{O}$ (5) (used)

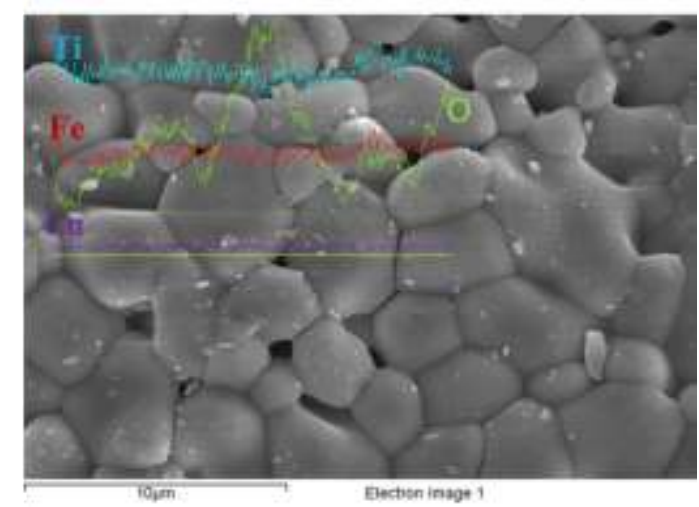

(h) $\mathrm{SCuO}(5)-\mathrm{I}$ (used)

Fig. 11. SEM images of ilmenite-based OCs before and after 20 redox cycle 
Table 4 Chemical composition of ilmenite-based OCs

\begin{tabular}{|c|c|c|c|c|c|c|c|c|}
\hline \multirow{2}{*}{$\begin{array}{c}\text { Chemical } \\
\text { Composition }\end{array}$} & \multicolumn{2}{|c|}{ Activated-I } & \multicolumn{2}{|c|}{$\mathrm{SK}_{2} \mathrm{O}(5)-\mathrm{I}$} & \multicolumn{2}{|c|}{ FG-I- $\mathrm{K}_{2} \mathrm{O}(5)$} & \multicolumn{2}{|c|}{$\mathrm{SCuO}(5)-\mathrm{I}$} \\
\hline & Fresh & Used & Fresh & Used & Fresh & Used & Fresh & Used \\
\hline $\mathrm{Fe}_{2} \mathrm{O}_{3}$ & 52.66 & 52.41 & 49.63 & 48.12 & 49.71 & 48.07 & 51.19 & 52.19 \\
\hline $\mathrm{SiO}_{2}$ & 5.39 & 5.21 & 5.58 & 7.33 & 5.19 & 7.01 & 4.59 & 4.44 \\
\hline $\mathrm{Al}_{2} \mathrm{O}_{3}$ & 3.57 & 4.52 & 4.04 & 4.93 & 4.09 & 4.46 & 3.44 & 3.74 \\
\hline $\mathrm{TiO}_{2}$ & 33.27 & 32.51 & 29.34 & 27.84 & 29.85 & 28.33 & 31.42 & 31.48 \\
\hline $\mathrm{CaO}$ & 0.8 & 0.77 & 0.87 & 1.04 & 0.81 & 1.17 & 0.82 & 0.73 \\
\hline $\mathrm{MgO}$ & 3.19 & 3.16 & 3.01 & 3.02 & 2.96 & 3.15 & 2.89 & 2.91 \\
\hline $\mathrm{Na}_{2} \mathrm{O}$ & 0.29 & 0.29 & 0.395 & 0.43 & 0.47 & 0.40 & 0.33 & 0.28 \\
\hline $\mathrm{K}_{2} \mathrm{O}$ & - & - & 5.19 & 5.08 & 4.95 & 5.17 & - & - \\
\hline $\mathrm{CuO}$ & - & - & - & - & - & - & 4.85 & 3.99 \\
\hline Balance & 0.83 & 1.13 & 1.75 & 2.21 & 1.97 & 2.24 & 0.47 & 0.24 \\
\hline
\end{tabular}

\section{Conclusions}

(1) The addition of K significantly improved the reactivity of ilmenite OCs with wet syngas and coal char. These CLC experiments achieved combustion efficiency > 95\%. When K-added ilmenite OCs were used in CLC experiments, the high reduction reactivity, the direct solid-solid reaction between coal char and OCs, and the catalytic function for the WGSR, make contributions to the improvement of the in-situ gasification.

(2) $\mathrm{SCuO}(5)-\mathrm{I}$ OC is an attractive oxygen carrier for the coal-fueled CLC. The coating of Cu-element enhanced the OC reactivity, oxygen transport capacity, and selectivity with wet syngas. Compared to external gasification, CLC experiments using Cu-coated OCs, improved the gasification rate $>100 \%$. The combustion efficiency of CLC was significantly enhanced to $95 \%$, comparable to $87.5 \%$ of combustion efficiency using the activated ilmenite OCs. The Cu-element coating effectively hindered iron-element segregation, and the particle integrity was maintained during multiple redox cycles.

(3) Ca-, Ni- and Mn-added ilmenite-based OCs did not show promising prospects for the coal-fueled CLC.

(4) Some key considerations for OC development as follows: a.) The evaluation of the OC reactivity must include the influence of steam in the fuel gas. Steam is an essential component for enhancing gasification of CLC, but significantly inhibits OC's reduction reaction. b.) The in-situ gasification rate of CLC can be correlated with the OC's reduction reactivity. In this correlation, increases in OC's reactivity showed less improvement of gasification rate than expected because char gasification is the limiting step. c.) The $\mathrm{OC}$ ability of converting syngas to $\mathrm{CO} 2$ and $\mathrm{H} 2 \mathrm{O}$ is an important performance for the full combustion of intermediate syngas in the fuel reactor. d.) The strong OC catalytic function for the WGSR could be an effective way to improve gasification rate and combustion efficiency of coal-fueled CLC.

\section{Acknowledgement}

The authors want to thank the US Department of Energy (US-DOE) for its financial support on the US-China CERC 2.0 project. The Kentucky Energy and Environment Cabinet Department for Energy (Development and Independence Grant Program) and Energy Research, the Carbon Management Research Group Consortium at the University of Kentucky, Center for Applied Energy Research (UKy-CAER) is also greatly appreciated. 


\section{References}

[1] Adanez J, Abad A, Francisco GL, Gayan P, Luis FD. Progress in chemical-looping combustion and reforming technologies. Prog. Energy Combust. Sci. 2012; 38(2): 215-282.

[2] Li F, Fan L-S. Clean coal conversion processes - progress and challenges. Energy Environ. Sci. 2008; 1: 248267.

[3] Guidance for NETL's Oxy-combustion R\&D Program: Chemical Looping Combustion Reference Plant Designs and Sensitivity Studies. DOE/NETL, 2014.

[4] Fan Z., Chen L, Liu F, Bao J, Heather N, Liu K. Coal Based Pressurized Chemical Looping Combustion Combined Cycle -Process development and Analysis. $4^{\text {th }}$ International Conference on Chemical Looping. 2016; Nanjing China.

[5] Rydén M, Johansson M, Cleverstam E, Lyngfelt A, Mattisson T. Ilmenite with addition of $\mathrm{NiO}_{2}$ as oxygen carrier for chemical-looping combustion. Fuel 2010; 89: 3523-3533.

[6] Mendiara T, García-Labiano F, Gayán P, et al. Evaluation of the use of different coals in Chemical Looping Combustion using a bauxite waste as oxygen carrier. Fuel 2013; 106:814-826.

[7] Arjmand M, Leion H, Mattisson T, Lyngfelt A. Investigation of different manganese ores as oxygen carriers in chemical looping combustion (CLC) for solid fuels. Appl Energy 2014; 113: 1883-1894.

[8] Azimi G, Keller M, Mehdipoor A, Leion H. Experimental evaluation and modeling of steam gasification and hydrogen inhibition in Chemical-Looping Combustion with solid fuel. Int J Greenhouse Gas Control 2012; 11: $1-10$.

[9] Abad A, Adánez J, Luis FD, García-Labiano F, Gayán P. Behavior of ilmenite as oxygen carrier in chemicallooping combustion, Fuel Process. Technol., 2012; 94(1):101-112.

[10] Linderholm C, Lyngfelt A, Cuadrat A, Jerndal E. Chemical-looping combustion of solid fuels - Operation in a $10 \mathrm{~kW}$ unit with two fuels, above-bed and in-bed fuel feed and two oxygen carriers, manganese ore and ilmenite. Fuel 2012; 102: 808-822.

[11] Berguerand $\mathrm{N}$, Lyngfelt A. Batch testing of solid fuels with ilmenite in a $10 \mathrm{~kW}_{\text {th }}$ chemical-looping combustor. Fuel 2010; 89:1749-1762.

[12] Bao J, Li Z, Sun H, Cai N. Continuous Test of Ilmenite-Based Oxygen Carriers for Chemical Looping Combustion in a Dual Fluidized Bed Reactor System. Ind. Eng. Chem. Res., 2013; 52: 14817-14827.

[13] Abad A, Adanez J, Cuadrat A, Francisco GL, et al. Kinetics of redox reactions of ilmenite for chemical-looping combustion, Chem. Eng. Sci., 2011; 66: 689-702.

[14] Cuadrat A, Abad A, Luis FD, et al. Prompt considerations on the design of Chemical-Looping Combustion of coal from experimental tests, Fuel 2012; 97: 219-232.

[15] Berguerand N, Lyngfelt A. Design and operation of a $10 \mathrm{~kW}_{\text {th }}$ chemical-looping combustor for solid fuels testing with South African coal, Fuel 2008; 87: 2713-2726.

[16] Berguerand $\mathrm{N}$, Lyngfelt $\mathrm{A}$. The use of petroleum coke as fuel in a $10 \mathrm{~kW}_{\text {th }}$ chemical-looping combustor. Int $\mathbf{J}$ Greenhouse Gas Control 2008; 2:169-179.

[17] Strule J, Orth M, Epple B. Chemical looping combustion of hard coal in a $1 \mathrm{MW}_{\text {th }}$ pilot plant using ilmenite as oxygen carrier. Appl Energy 2015; 157: 288-294.

[18] Lyngfelt A, Leckner B. A $1000 \mathrm{MW}_{\text {th }}$ boiler for chemical-looping combustion of solid fuels -Discussion of design and costs. Appl Energy 2015; 157:475-487.

[19] Florian M, Ajay RB, Alexander S, et al., Comparison of a new micaceous iron oxide and ilmenite as oxygen carrier for chemical looping combustion with respect to syngas conversion. Appl Energy 2014; 113: 1863-1868.

[20] Adanez J, Cuadrat A, Abad A, et al., Ilmenite activation during consecutive redox cycles in Chemical-Looping Combustion, Energy Fuels 2010; 24:1402-1413.

[21] Gayan P, Garcia-Labiano F, Cabello A, Luis FD, A bad A, Adanez J. Evaluation of the oxygen carrier particle lifetime in a Chemical Looping Combustion process. $22^{\text {th }} \mathrm{CFB}$, 2015, Turku, Finland.

[22] Bao J, Li Z, Cai N. Promoting the Reduction reactivity of ilmenite by introducing foreign ions in Chemical Looping Combustion. Ind. Eng. Chem. Res., 2013; 52: 6119-6128. 
[23] Azimi G, Mattisson T, Leion H, Rydén M, Lyngfelt A. Comprehensive study of Mn-Fe-Al oxygen-carrier for chemical-looping with oxygen uncoupling (CLOU). Int J Greenhouse Gas Control. 2015; 34:12-24.

[24] Chen L, Bao J, Kong L, Heather N, Fan Z, Liu K. The direct solid-solid reaction between coal char and ironbased oxygen carrier and its contribution to solid-fueled chemical looping combustion. Appl Energy 2016; 184:9-18.

[25] Siriwardane R, Tian H, Simonyi T, Poston J. Synergetic effects of mixed copper-iron oxides oxygen carriers in chemical looping combustion. Fuel 2013; 108: 319-333.

[26] Khedr M.H., Bahgat M., Radwan M., Abdelmaksoud H.S. Effect of $\mathrm{Cu}^{2+}$ on the magnetic properties and reducibility of $\mathrm{Fe}_{2} \mathrm{TiO}_{5}$.J. Mater. Process. Technol. 2007; 190:153-159.

[27] Kang K-S, Kim C-H, Bae K-K, et al. Oxygen-carrier selection and thermal analysis of the chemical-looping process for hydrogen production. Int. J. Hydrogen Energy 2010; 35(22):12246-12254.

[28] Xu L, Edland R, Li Z, Leion H, et al., Cu-modified manganese ore as oxygen carrier for chemical looping combustion. Energy fuels 2014; 28(11): 7085-7092.

[29] Yang W, Zhao H, Ma J, et al. Copper-decorated hematite as an oxygen carrier for in situ gasification Chemical Looping Combustion of coal. Energy Fuels 2014; 28: 3970-3981.

[30] Keller M, Leion H, Mattisson T, Lyngfelt A. Gasification inhibition in chemical-looping combustion with solid fuel. Combust. Flame 2011; 158(3): 393-400.

[31] Shulman A, Cleverstam E, Mattisson T, Lyngfelt A. Chemical-Looping with oxygen uncoupling using Mn/Mgbased oxygen carriers-Oxygen release and reactivity with methane. Fuel 2011; 90:941-950.

[32] Schwebel GL, Leion H, Krumm W. Comparison of natural ilmenites as oxygen carriers in chemical-looping combustion and influence of water gas shift reaction on gas composition. Ind. Eng. Chem. Res. 2012; 90:13511360 .

[33] Garc1'a-Labiano F, Luis FD, Gaya'n P, Abad A, Ada'nez J. Fuel reactor modeling in chemical-looping combustion of coal: 2-simulation and optimization. Chem. Eng. Sci. 2013; 87:173-182.

[34] Callaghan CA. Kinetics and Catalysis of the Water-Gas-Shift Reaction: A micro kinetic and graph theoretic approach. Doctoral thesis 2006; 116. 